NBER WORKING PAPER SERIES

\title{
HAPPY NEWS FROM THE DISMAL SCIENCE: REASSESSING JAPANESE FISCAL POLICY AND SUSTAINABILITY
}

\author{
Christian Broda \\ David E. Weinstein \\ Working Paper 10988 \\ http://www.nber.org/papers/w10988 \\ NATIONAL BUREAU OF ECONOMIC RESEARCH \\ 1050 Massachusetts Avenue \\ Cambridge, MA 02138 \\ December 2004
}

We wish to offer special thanks to Takatoshi Ito and Hugh Patrick for providing us with tremendously detailed comments on an earlier draft. We also wish to thank Donald Davis, Rick Katz, Kenneth Kuttner, David Lebow, Robert Masden, Peter Morgan, Adam Posen and Cedric Tille for helpful comments. David Weinstein wishes to thank the Center for Japanese Economy and Business for providing research support for this project. The views expressed here are those of the authors, and do not necessarily reflect the position of the Federal Reserve Bank of New York, the Federal Reserve System, or any other institution with which the authors are affiliated. The views expressed herein are those of the author(s) and do not necessarily reflect the views of the National Bureau of Economic Research.

() 2004 by Christian Broda and David E. Weinstein. All rights reserved. Short sections of text, not to exceed two paragraphs, may be quoted without explicit permission provided that full credit, including $\odot$ notice, is given to the source. 
Happy News from the Dismal Science: Reassessing Japanese Fiscal Policy and Sustainability Christian Broda and David E. Weinstein

NBER Working Paper No. 10988

December 2004

JEL No. E6, H5, H6

\section{ABSTRACT}

We analyze fiscal policy and fiscal sustainability in Japan using a variant of the methodology developed in Blanchard (1990). We find that Japan can achieve fiscal sustainability over a 100-year horizon with relatively small changes in the tax-to-GDP ratio. Our analysis differs from more pessimistic analyses in several dimensions. First, since Japanese net debt is only half that of gross debt, we demonstrate that the current debt burden is much lower than is typically reported. This means that monetization of the debt will have little impact on Japan's fiscal sustainability because Japan's problem is the level of future liabilities not current ones. Second, we argue that one obtains very different projections of social security burdens based on the standard assumption that Japan's population is on a trend towards extinction rather than transitioning to a new lower level. Third, we demonstrate that some modest cost containment of the growth rate of real per capita benefits, such as cutting expenditures for shrinking demographic categories, can dramatically lower the necessary tax burden. In sum, no scenario involves Japanese taxes rising above those in Europe today and many result in tax-to-GDP ratios comparable to those in the United States.

Christian Broda

Federal Reserve Bank of New York

christian.broda@ny.frb.org

David E. Weinstein

Department of Economics

Columbia University

420 W. 118th Street

MC 3308

New York, NY 10027

and NBER

dew35@columbia.edu 
Happy News from the Dismal Science: Reassessing Japanese Fiscal Policy and Sustainability

\section{Christian Broda and David E. Weinstein}

The idea that Japan is on the verge of a government fiscal crisis is such a commonplace that it seems pointless to venture back into well-trodden terrain. ${ }^{1}$ The news media is rife with reports of government debt to GDP ratios approaching 200 percent, budget deficits amounting to 10 percent of GDP, lower future growth due to a shrinking labor force, and an aging population that will result in a doubling of the ratio of public pension and medical benefit recipients to the employed. Add to this the announcement by Moody's that it downgraded Japanese government debt to a level equal to that of Mauritius and several other developing countries, and it is no wonder that so many people have predicted a meltdown of government finances.

And yet, there are reasons for questioning these dire predictions. To understand why, remember that a fiscal crisis that could not be resolved through higher taxes or lower expenditures would result in one of two outcomes: either the government would default on its debt or, more likely, it would be forced to print money and inflate in order to cover its obligations. In either case, expectation of a fiscal crisis would imply that holders of long-term government debt face considerable risk. If this risk is high, then the yield on long-term government bonds should be higher today in order to compensate bond holders for future expected losses due to default or inflation. In other words, the long-term bond market is designed to price inflation and default risk. However, in 2003, the yield on newly-issued 20-year Japanese government bonds (JGB's) fluctuated between $0.8 \%$ and $1.9 \%$ while the yield for 10 -year bonds 
moved between $0.5 \%$ and $1.5 \%$ (MOF website). Given that the amount of long-term JGB's outstanding was 172 trillion yen in 2001 or 34 percent of GDP, this suggests that there is a vast amount of money betting that Japan will pay off its debt through conventional fiscal policy. ${ }^{2}$

One possible explanation for the calmness of the bond market is that bond holders are confused or that there is some market imperfection underlying the low rates. ${ }^{3}$ While this might be true, the vast amount of money betting against a fiscal crisis suggests that it might be fruitful to consider an alternative explanation - namely that bond holders actually know what they are doing and that the stories of a fiscal meltdown are ultimately not that convincing. In order to explore this, we will question the data, the theory, and the forecasts underlying the predictions of a fiscal crisis. Our findings suggest that by using the correct data, better theory, and more sensible forecasts, our understanding of the history and future of fiscal policy in Japan is radically altered.

1 Theory: What do we mean by fiscal sustainability?

The key policy question is whether Japan will be forced into a fiscal crisis. To answer this, it is necessary to determine just what a sustainable fiscal policy is. Only then is it possible to clearly identify a set of policies that are consistent with fiscal sustainability and that can guide policy makers to achieve this goal.

Following Blanchard (1990), we define a fiscal policy as sustainable if the current policy can be continued indefinitely with a stable government debt-to-GDP ratio. If the deficits are too

\footnotetext{
${ }^{1}$ See, for example, Asher and Dugger 2001), Dekle (2002), Madsen (2002), and Fukao (2003).

${ }^{2}$ Ideally, we would like to know the value of long-term government debt in private hands. Unfortunately, we were not able to locate this information.

${ }^{3}$ For example, Fukao (2002) writes, "They [holders of Japanese bonds] are blindly buying government-backed financial assets even though the credit worthiness of the government is rapidly deteriorating. This negative bubble is clearly unsustainable."
} 
high, the stock of government debt expands until the private sector ceases being willing or able to supply the government with credit, forcing a crisis in the form of monetizing or repudiating the debt. Similarly, if surpluses are too high, the government is forced to purchase private assets and gradually nationalize the economy. Of course, many short run factors - macroeconomic shocks, fiscal stimulus packages, wars, etc — can cause a country's tax rate to deviate from this level in the short run. As such, the concept is most useful when thinking about long-run average tax rates.

Although we deal with certain "irrational" limits on debt, we are more interested in the inevitability of a fiscal crisis than in whether one can construct scenarios in which a solvent government can be forced into crisis. Also, remember that irrationality, multiple equilibria, and political factors can make fiscal policy more likely to be sustainable. For example, a major question in public economics is why governments do not default even when the country would be better off doing so.

Note that our analysis cannot address unsustainability that may arise even if the fundamentals suggest it is sustainable. Unsustainability might occur because of irrational actions by markets, multiple equilibria (for example, a default arising because everyone expects default even though the government could honor its obligations if people continued to believe that it would), and political reasons for default.

Critical to determining whether a fiscal policy is sustainable is understanding the past and predicting the future. Reviewing past fiscal policy is a critical component of understanding the level of current liabilities of the Japanese government, as well as understanding what long-run average baseline tax and expenditure levels one should use in assessing sustainability. Unfortunately, the policy debate over the level of Japanese debt reflects confusion among some 
academics, market analysts, and government officials who often use gross debt levels as their starting point to assess Japan's fiscal sustainability which is equivalent to treating Japan's financial assets as worthless. This confusion can lead to an extremely misleading understanding of the current fiscal situation. Moreover, as Posen (1998) has pointed out, there also is deep confusion over what is meant by fiscal policy in Japan.

Forecasts of the future are, of course, problematic. Therefore, we provide a wide range of forecasts and demonstrate robustness over many "reasonable" views of the future. These forecasts require us to make projections about population and income dynamics, as well as what implicit and explicit obligations current and future generations have. We present the results from over 60 different scenarios about the future covering a wide range of possibilities of GDP and population growth rates, pension benefits, social welfare policies, monetary policies, and time horizons.

As this discussion suggests, there is more than a little art in constructing sustainability numbers. That, however, does not mean that they are useless. In particular, sustainability calculations can give us guidance about how much adjustment is needed to achieve a particular policy and, moreover, what policy is likely to be implemented. For example, Japanese may believe that Japan should dramatically raise its per capita public pension benefits, and improve medical benefits for the elderly, dramatically expand per capita expenditures on younger people in the form of education and other social expenditures, while also expanding public investment as a share of GDP. That vision is not feasible without a significant rise in taxes. However, if one adopts a view that shifts in demographic categories imply proportional shifts in government transfers to that category - fewer children imply fewer schools rather than empty classrooms, 
for example — then our calculations suggest that sustainability may well be feasible with little adjustment.

Indeed, the main contribution of this chapter is to argue that the current debt and deficit levels in Japan have almost no impact on long-run sustainability calculations and that the "right" long-run tax level simply depends on the forecast of the "right" long-run expenditure level. As a result, the monetization or reduction of today's debt level does not have much impact on the sustainable tax rate. Put simply, if one forecasts that Japan will need to raise per capita government expenditures and transfers a lot in order to pay better pensions and elderly health costs, Japan's tax rates will have to rise to the levels that we see in a typical European country today. If Japan maintains a generous, but not too generous, growth in benefits, future outlays and taxes will look more like the current ones in the United States. Neither of these scenarios strikes us as reasons to worry about fiscal sustainability.

2 Computing Sustainability: Theory

It is useful to begin the description of the methodology used in this paper by reviewing some basic fiscal arithmetic that underlies any discussion of sustainability (c.f. Blanchard 1990). The government's intertemporal budget constraint is the natural starting point.

For our purposes, government expenditures (including transfers) are divided into one of three categories: public pension payments and medical benefits for the elderly, $H_{i}$; all other expenditures, except interest, $G_{t}$; and interest on the debt, where $B_{t}$ is the level of government net debt and $i_{t}$ is the interest rate on that debt. The elderly are defined, conventionally, as those 65 or older. 
In period $t$ it can be stated as follows:

$$
\left(G_{t}+H_{t}+i_{t} B_{t-1}\right)-T_{t}=\left(B_{t}-B_{t-1}\right)+\left(M_{t}-M_{t-1}\right)
$$

where $T_{t}$ stands for fiscal revenues (e.g. taxes), $H_{t}$ is transfers to the old, and $G_{t}$ is other government non-interest expenditures. $B_{t}$ and $i_{t}$ are the level of government net debt and the interest rate on that debt in period $t$, respectively, and $M_{t}$ is the money supply (i.e. base money) in period $t$. Equation (1) simply states that fiscal deficits (the left-hand side of (1)) can be financed by issuing new debt, $\left(B_{t}-B_{t-1}\right)$, or through changes in money supply, $\left(M_{t}-M_{t-1}\right)$.

It is useful to rewrite the government budget constraint in terms of ratios to GDP (in nominal terms), indicated by lowercase letters. Then, rearranging the government's budget constraint enables us to obtain the following expression of the government debt-to-GDP ratio, $b_{i}$ :

$$
b_{t}=g_{t}+h_{t}-\tau_{t}+\frac{1+i_{t}}{1+\eta_{t}} b_{t-1}-\lambda_{t} m_{t}
$$

Here $\tau_{t}$ is $T_{t} / \mathrm{GDP}_{t}, \eta_{t}$ is the growth rate of nominal GDP, and $\lambda_{t}$ is the growth rate of the nominal money supply. For reasons that will become clear below, we assume that $\left(i_{t}-\eta_{t}\right) \geq 0$, that is, the interest rate is greater than the growth rate of GDP.

Expressed in this way, the budget constraint implies that the evolution of the debt-toGDP position, $b_{t}$, is a function of three components. The first component reflects the impact of current fiscal policy on $b_{t}$. A positive primary fiscal deficit, $g_{t}+h_{t}-\tau_{t}>0$, raises $b_{t}$. The second component reflects the burden of the past debt level on the current level of $b_{t}$. With a nominal interest rate on government debt that exceeds the nominal growth rate of GDP, interest rate payments grow at a faster rate than GDP which implies that, ceteris paribus, the debt-to-GDP ratio, $b_{t}$, will increase relative to $b_{t-1}$. Third, conditional on the level of initial debt and primary 
deficit, a positive growth rate of the money supply implies a lower level of $b_{t}$ because expansions in the money supply reduce the amount of debt (bonds) held by the private sector.

Equation (2) can be easily expanded to examine the relationship between debt-to-GDP ratios $n$ years into the future with today's debt-to-GDP ratios. For notational simplicity, it is assumed that $i_{t}$ and $\eta_{t}$ are constant over time, and that today's level of debt-to-GDP is given by $b_{0}$. We can then express the level of debt-to-GDP in period $n$ as:

$$
b_{n}=\sum_{t=1}^{n}\left(\frac{1+i}{1+\eta}\right)^{n-t}\left(g_{t}+h_{t}-\tau_{t}-\lambda_{t} m_{t}\right)+\left(\frac{1+i}{1+\eta}\right)^{n} b_{0}
$$

This equation is central for the definition of fiscal sustainability that we adopt below. It states that the level of debt-to-GDP $n$ periods into the future is the sum of the accumulated primary deficits that grow at the rate $\left(\frac{1+i}{1+\eta}\right)$, and the value of the initial level of debt raised by the same rate.

\subsection{Fiscal Sustainability Defined}

We can now proceed to define the concept of fiscal sustainability and derive an indicator that renders this definition operational. While there are several ways to define fiscal sustainability, we will follow closely the method suggested by Blanchard et al (1990). They define a fiscal policy as sustainable if the path of taxes and expenditures $\left.\left\{g_{t}, h_{t}, \tau_{t}\right\}\right|_{t=1, \ldots, n}$ is such that the ratio of debt-to-GDP eventually converges back to its initial level over the finite horizon under consideration. ${ }^{4}$

\footnotetext{
${ }^{4}$ A different approach has been suggested by Auerbach and Kotlikoff (1995) who uses generational accounting to assess fiscal sustainability. This methodology compares tax burdens of current and future generations and defines a tax rate as sustainable if future generations need not pay higher tax rates than current generations. The two approaches are conceptually similar in that they are both based on the government's intertemporal budget constraint.
} 
Formally, by rearranging and pre-multiplying both sides of (3) by $\left(\frac{1+\eta}{1+i}\right)^{n}$ we obtain the crucial equation for sustainability:

$$
\sum_{t=1}^{n}\left(\frac{1+\eta}{1+i}\right)^{t}\left(\tau_{t}-g_{t}-h_{t}+\lambda_{t} m_{t}\right) \geq b_{0}-b_{n}\left(\frac{1+\eta}{1+i}\right)^{n}
$$

The condition for fiscal sustainability $n$ years into the future is that $b_{n}=b_{0}$. In other words, a fiscal policy is sustainable in $n$-years time if the present discounted value of the ratio of primary surpluses to GDP plus of monetary financing is greater than or equal to the difference between the current level of the debt-to-GDP ratio and the desired discounted debt-to-GDP ratio $n$ periods ahead. ${ }^{5}$ Simply put, this implies that a government with outstanding debt that faces interest rates in excess of growth rates $\left(i_{t}>\eta_{t}\right)$ must eventually run a primary surplus or increase base money in order to achieve fiscal sustainability.

Several characteristics of a sustainable fiscal policy are noteworthy. First, there are a number of conceptually equivalent ways of deriving an indicator that assesses sustainability from equation (4). We will use an indicator of sustainability that relies on government revenues. ${ }^{6}$ This enables us to answer the question of how costly will it be for Japan to stabilize its government debt and pay for a particular set of policies. As in Blanchard et al. we opt for an index of fiscal sustainability given by $\left(\tau^{*}-\tau\right)$, where $\tau^{*}$ is the constant tax rate $\left(\tau_{t}=\tau^{*} \forall t\right)$ that solves (4)

\footnotetext{
${ }^{5}$ Unlike the infinite horizon case, the level of outstanding debt in period $n$ discounted to today (i.e., the last term in equation (4)) is not zero.

${ }^{6}$ A different indicator could be the level of initial debt, $b_{0}^{*}$, such that, for a given path of fiscal and monetary policy $\left.\left\{\lambda_{t}, g_{t}, h_{t}, \tau_{t}\right\}\right|_{t=1, \ldots, n},(4)$ is satisfied. We could then compare this level of debt to the actual level of debt to have a sense of the extent of fiscal adjustment that is needed.
} 
with equality for a given path of $\left.\left\{\lambda_{t}, g_{t}, h_{t}, b_{0}\right\}\right|_{t=1, \ldots, n}$, and $\tau$ is the actual tax revenues-to-GDP ratio. $^{7}$ Formally,

$$
\tau^{*}=\frac{i-\eta}{1+\eta}\left[b_{0}+\left(1-\left(\frac{1+\eta}{1+i}\right)^{n}\right)^{-1} \sum_{t=1}^{n}\left(\frac{1+\eta}{1+i}\right)^{t}\left(g_{t}+h_{t}-\lambda_{t} m_{t}\right)\right]
$$

This indicator has several desirable properties. First, $\tau^{*}$ has a simple interpretation. It is the constant tax rate that achieves an unchanged debt-to-GDP ratio over the relevant horizon, given forecasts of government spending. . In addition, the difference between $\tau^{*}$ and $\tau$, the tax "gap", is a measure of the size of the adjustment needed to attain sustainability were the adjustment to take place today. In general, what a positive tax gap implies for different countries depends on the initial level of $\tau$. If $\tau$ is high, a positive gap is probably more worrisome than if $\tau$ is low, as the chance of having to resort to monetization or repudiation increases if existing tax pressures are already high.

Another important characteristic of sustainable fiscal policy is related to the role played by the discount factor $\left(\frac{1+\eta}{1+i}\right)$. Consider the case where the average nominal interest rate on government bonds is lower than the nominal growth rate, $i_{t}-\eta_{t}<0$, which is known as the "dynamic inefficiency" case. In such a case, or when capital accumulation has exceeded the optimal level, ${ }^{8}$ equation (3) implies that an economy can run a constant deficit forever without ever having to monetize or worry that it's debt-to-GDP ratio will explode. Here, concerns on explosive debt-to-GDP paths are unwarranted because the economy can grow out of any debt problem. Interestingly, we have observed long periods in Japan's history where $i_{t}-\eta_{t}<0$ (i.e.

\footnotetext{
${ }^{7}$ The same approach could have been used to compute a sustainable spending rate given the forecast of government revenues.
} 
the average nominal interest rate on government bonds was lower than the nominal growth rate). ${ }^{9}$ Nevertheless, we will follow convention and assume that $i_{t}-\eta_{t}$ is positive. ${ }^{10}$ In the next section, we calculate the sustainable tax rate for different values of $i_{t}-\eta_{t}$ and we discuss the most relevant case for Japan in the future.

A requirement that is not completely justified from this definition of sustainability is that the ratio of debt-to-GDP has to return to its initial level rather than any other finite level of debt. For instance, a policy aimed to stabilize the debt-to-GDP ratio at 40 percent rather than 20 percent should not be characterized as an unsustainable policy. While this is certainly true, changing the level of finite desired debt $n$ periods ahead has a relatively small effect on the sustainable tax rates when $n$ is large enough. This is because of discounting, which implies that two different levels of debt-to-GDP far in the future, say 100 years from now, can arise from nearly exactly the same sustainable tax rate today; in the limit, as $n$ grows to infinity, they make no difference. ${ }^{11}$ Finally, note that the fiscal policy that is sustainable for $n$ periods ahead many not be sustainable over a shorter period. For example, we will show that it is much harder for Japan to keep the debt level stabilized over a 35 year period than over a 100 year period.

\footnotetext{
${ }^{8}$ See Abel et al (1995) and Frisch (1995) for a discussion of issues related to dynamic efficiency.

${ }^{9}$ The same is true for the average of OECD countries. During the 70s and most of the 80 s the average difference across countries between nominal interest rates and nominal growth rates was negative. For a simple explanation of dynamic efficiency see Romer (1996).

${ }^{10}$ This is subject to a caveat raised by Abel et al. They show that under uncertainty the condition for dynamic efficiency differs from the condition that interest rates have to exceed growth rates. In particular, they demonstrate that a negative $i_{t}-\eta_{t}$ does not necessarily imply that the economy of major industrialized countries is dynamically inefficient. Obviously, if Japan's long-run growth will exceed the interest rate, then Japan's fiscal situation will be brighter than what we discuss in this paper.

${ }^{11}$ Formally, the condition for sustainability when $n$ goes to infinity implies that the limit of the second term of the RHS of (4) is equal to zero.
} 


\section{Computing Sustainability}

The previous section made clear that in order to perform a sustainability calculation one must know what the current level of debt is, what the evolution of government expenditures is likely to be, what economic growth is likely to look like, and what is likely to happen with monetary policy. We will make estimates of each in turn.

\subsection{Government Debt}

Conceptually, government debt in a sustainability calculation corresponds to the current amount of net liabilities held by the government. ${ }^{12}$ In practice, this is government assets less liabilities or net government debt. One wants to focus on net debt because government borrowing used to finance government lending does not need to be paid off with taxes. Revenue generated by the repayment of government loans can be used to cover borrowed funds in much the same way that a bank's lending portfolio offsets the liabilities created by the deposit accounts. (We will make adjustments for bad loans later.) Given that the Bank of Japan (2004) reports that 40 percent of all lending in Japan is made by public financial institutions, focusing only on the liability side of the balance sheet without adjusting for the substantial assets on the other side, can easily lead to an overly pessimistic view of the government's financial health. Similarly, Japan's foreign exchange reserves (financed by bond issues), which total to 18 percent of GDP [see the Ito and Patrick chapter in this volume], constitute an important reason why net and gross debt diverge.

The accounting method used in Japan for transfers of funds within the government can create misunderstanding regarding debt levels. Certain accounts run surpluses because tax

\footnotetext{
${ }^{12}$ Technically we should add non-financial assets to the balance sheet. We do not because we assume that the government will never sell any of its real estate holdings or other real assets.
} 
revenue exceeds expenditures (e.g. public pensions until 1994 in the case of Japan) while other accounts run deficits. In a consolidated or "unified budget" accounting system, all tax revenue is pooled together and bonds are issued to cover any aggregate difference between expenditures and revenues. In the Japanese system, by contrast, accounts are kept separate, and so surpluses in one account are lent to another. For example, surplus funds in the social security system may be used to make deposits in other government accounts, e.g. the Fiscal Investment and Loan Program. When these transfers occur, the social security account receives an asset in the form of a deposit and the other branch of the government records a liability of the same magnitude.

This system is useful for understanding the history of past intra-governmental transfers and expectations of future transfers, but it can be very confusing when thinking about the net worth of the public sector. For example, in a consolidated accounting system, if the social security tax raises one hundred yen of revenue and rest of the government spends one hundred yen, the debt of the government would equal zero. In Japanese system, however, this transfer of say, one hundred yen, often involves the purchase of a bond or the creation of a government deposit account. Hence, the same transfer would involve the general account borrowing from the social security system, which creates a liability for the general account of one hundred yen, and the social security system obtaining an asset (i.e a deposit in the government) worth 100 yen. In both accounting systems, the financial implications to the aggregate public sector are identical, but the accounting practices would make the balance sheets look quite different - the consolidated government debt would be zero, but the unconsolidated accounts would show a gross Japanese government debt of one hundred yen. Of course, in the unconsolidated accounts the Japanese government would have a one hundred yen asset to offset the one hundred yen liability so net debt in the two systems would be identical, but the point remains that the gross 
debt would look quite different. This underscores the importance of looking at public assets less liabilities or net government debt.

Unfortunately, the most commonly used number in popular and some academic discussion of Japanese debt is what is called "gross debt" in official government statistics. It corresponds to total liabilities of the central and local governments including the social security system. In FY2002, this number stood at 161 percent of GDP, which was higher than any other country in the OECD [BOJ and OECD website]. However, just as it would have been wrong to have assumed that Japan was in worse financial health in the previous example because the government owed one hundred yen to itself, one should be deeply skeptical that gross debt numbers contain much - if any - information about fiscal health. Indeed, they can be highly misleading. To make this point concrete, the value of the net debt of the Japanese public sector was only 64 percent of GDP in FY2002. ${ }^{13}$ In other words, the gross debt number overstates the fiscal problem by a factor of 2.5! To put this into perspective, Japan's level of net debt in 2002 was not that much above the Maastricht Treaty's upper bound of 60 percent for membership in the EU and well below the level of high debt countries like Italy and Belgium.

The standard net debt number, however, also overstates Japanese government debt levels because it does not take into account bonds held by the Bank of Japan. ${ }^{14}$ How to treat holdings by the BOJ depends on what one's forecast of monetary policy is. If one assumes that the money base will not change as a share of GDP, then debt held by the central bank never needs to be repaid and one does not need to count the bonds held by the central bank as a liability of the

\footnotetext{
${ }^{13}$ This number is calculated by summing together the net debts of the Japanese government, postal savings, and government financial institutions as reported in the BOJ Flow of Funds website. Net debt of social security and the central and local governments in these accounts is 70\% of GDP for fiscal year 2002. This is very close to the OECD's number of $71 \%$ for calendar year 2002 as reported on the OECD website. By contrast, the OECD reports net debt to GDP ratios for Belgium, Italy, and the US are $96 \%, 94 \%$, and $44 \%$.

${ }^{14}$ Lebow (2004) provides a more detailed analysis of the interaction between net debt and monetary policy.
} 
consolidated government. This will constitute our baseline scenario. However we will also consider the implications of a substantial increases and decreases in the monetary base. The reason why this matters is that the BOJ owns a large amount of the outstanding JGB's. Although bonds held by the BOJ are not counted as part of the government net debt, the 80 trillion yen worth of government securities held by the BOJ and 10 trillion yen in BOJ financial surplus in 2002 means that if one assumes that the money base will not change, the net debt of the consolidated Japanese public sector was only 46 percent - only 29 percent of the number that is typically used. ${ }^{15}$

Pessimists will be quick to point out that this number does not make allowances for future obligations of the Japanese government. These allowances will enter into our sustainability calculation, but they should not be counted as a part of current net liabilities. Doing so is worse than wrong; it can lead to misleading predictions about the efficacy of monetary policy in reducing the debt.

Suppose, for example, that it is true that Japan faces major future deficits due to the aging of the population. Now consider the impact of a one time unanticipated 100 percent rise in the Japanese price level that cuts the value of nominal government debt in half. Since the level of net debt is 46 percent of GDP, then this large inflation would only reduce the real government debt by a relatively modest 23 percent of GDP and do nothing about the future liabilities (assuming they are all indexed to inflation). By contrast, if one mistakenly counted future liabilities as current liabilities by working with the gross debt figure of 161 percent, one would erroneously calculate that a doubling in the price level would reduce the real debt burden of the Japanese public sector by 81 percent of GDP! The difference between the numbers arises from the fact

\footnotetext{
${ }^{15}$ Numbers are from the BOJ's flow of funds website, spreadsheet fys1100e.xls. Bond holdings are "Central government securities and FILP bonds" held by the BOJ. Operating surplus is "Financial surplus or deficit
} 
that the gross debt number double counts (or really quadruple counts) current liabilities and undercounts future liabilities. As this simple example makes clear, using the right data can make a big difference for policy analysis. If one erroneously uses gross debt instead of net debt, one would be tempted to see inflation as a solution to Japan's debt problem, when in fact it is not because, as we will soon see, the problem is not the current level of liabilities but the future level. $^{16}$

\subsection{Government Bad Loans}

One issue with government debt levels that is more difficult to estimate are bad loans made by the government to the private sector or bad loans made to public enterprises. These could mean that the official debt statistics understate the true level of debt because some of the assets (e.g. loans) may have a market value below book value. Constructing estimates of the magnitude of these bad loans is a serious undertaking in its own right and beyond the scope of this paper. We therefore opted to use Doi and Hoshi's (2002) estimates of bad loans to local governments and public enterprises as an estimate.

However, Doi and Hoshi overstate the consolidated government bad loan problem for two reasons. First, Doi and Hoshi were interested in defaults by local governments to the central government. However, failure to repay loans made between branches of the government do not change net debt since a loss to the central government arising by a default on a loan payment by a local government would be offset by the gain accruing to the local government from writing off the loan. This suggests that we should reduce the Doi and Hoshi estimate by the 35-40 trillion

(Transactions)"

${ }^{16}$ Takayama and Kitamura (1999) arrive to a similar conclusion using a different approach called "Generational Accounting". They find that most of the generational imbalances are due to future demographic change rather than the existing level of debt. 
yen that constitute losses from government loans to local governments. Second, the Doi and Hoshi paper performs a present discounted calculation of future losses by public enterprises and so using their numbers overstates the level of current liabilities.

On the other hand, Doi and Hoshi had no information about hidden bad loans that have not appeared on any balance sheet, so it is possible that their estimates are not such overestimates of hidden government liabilities as one might expect from the above. Moreover, the Hoshi and Kashyap chapter in this volume estimates that the banking sector would require as much another 35 trillion yen to be adequately capitalized. If some portion of this money must come from the government then this should be added to the level of government liabilities.

We therefore decided to take Doi and Hoshi's 79 trillion yen estimate of bad loans to local government and public enterprises as our proxy for hidden liabilities on public corporation and bank balance sheets that will need to be covered by the government. This raises the net debt ratio up to 62 percent of GDP in fiscal year 2002 and serves as the basis for the net debt ratio that we use in the remainder of the paper.

\subsection{Current Government Outlays}

Although it is commonly argued that Japan's large deficits arose from large fiscal stimulus packages, there is ample reason to be skeptical about this claim. Once again data definitions matter, and there is much to be gained by carefully using the right numbers. The starting point for understanding Japanese government expenditures and revenues is Figure 2.1, which plots the evolution of revenues and expenditures as a share of GDP over the last two decades. The plot makes plain two points. First, there was a substantial rise in government 
expenditures after 1991, and secondly, tax revenues fell by about 3 percentage points of GDP (which the underlying data reveal was largely due to a decline in personal income tax revenue). Adam Posen and Kenneth Kuttner have explored the reasons for movements in expenditures and tax revenues. One important result in Kuttner and Posen (2002) is that in all likelihood almost the entire precipitous decline in tax revenues that we see in Figure 2.1 is due to the recession. They show that if we assume a tax elasticity of 1.25 , then the increase in the output gap implies that had economic growth in Japan not slumped, Japan's government budget deficit would have been substantially smaller. In other words, if Japanese economic performance improves, we should expect to see a substantial increase in Japanese government revenues as a share of GDP. This underscores the importance of using a long-run tax-to-GDP ratios as a baseline in our calculations rather than their current values.

To understand the source of the increase in the ratio of government expenditures to GDP, we need to delve deeper into the data. A common misconception is that this is the result of a massive fiscal stimulus. First, it is important to remember that an increase in this ratio can occur without a fiscal stimulus: holding fixed the growth rate of government expenditures, declines in economic growth will imply relatively higher expenditure-to-GDP ratios. Posen (1998) sharpens this point by showing that the reputed fiscal stimulus is completely absent from the national accounts data after 1996.

Figure 2.2 presents both the government outlay data and the national accounts public demand data (public demand being the sum total of all government expenditures on goods and services in the system of national accounts). As the figure makes clear, although government outlays rose dramatically in the 1990's public demand was fairly flat after 1996. This gives rise to what might be called "the mystery of the missing stimulus" - why is it that government 
outlays are rising in the government outlay data but public demand is flat in national accounts data?

The answer once again goes back to data definitions. Public demand in the national accounts covers all public expenditures for goods and services. As the name suggests, movements in this variable directly shift Japanese aggregate demand and provide a major basis for government stimulus policies. Looking more closely at the graph, we see that between 1991 and 1996 public demand rose by 4 percentage points of GDP while government outlays rose by 5 percentage points: indicating that 80 percent of the increase in government outlays was due to a conventional fiscal stimulus policy. After 1996 public demand has been flat.

Moreover, the level of fiscal stimulus has not been at a particularly high level relative to historical patterns. It is worth pausing for a moment to consider this fact. Despite all the discussion in Japan about fiscal policies that built "bridges to nowhere", the data clearly state that the dramatic expansion in government outlays in recent years did not arise from public works projects [see Economic and Social Research Institute data cited in references]. In other words, the rise in government expenditures in recent years must be due to something other than the purchase of goods and services. This is even true if we slice the data more finely and focus on public works projects. The ratio of public investment to GDP averaged 0.077 in the 1980s and 0.078 in $1990 \mathrm{~s}$.

Government outlay data includes two important categories of expenditures that are not included in the national account's definition of public demand: interest and transfer payments. The reason for this is that interest and transfer payments do not entail the purchase of goods and services and therefore do not directly increase in aggregate demand. Interest payments by government institutions probably do not even indirectly affect aggregate demand since it is hard 
to imagine that it matters to households whether their interest bearing securities are JGB's or bank deposits. Transfer payments, on the other hand, can indirectly affect aggregate demand by raising private consumption. This will happen if they are not anticipated or if households that receive them are credit constrained. When the Japanese government handed out 20,000 yen coupons to families with children as part of a fiscal stimulus plan, it was a transfer payment that was not fully anticipated and may have gone to households that could not borrow to spend more [c.f. Hsieh and Shimizutani (2001)]. As a result, the coupon plan may have stimulated some expenditure. However, when a worker retires with positive net wealth and collects social security pension payments, this probably does not affect aggregate demand because workers typically adjust their lifetime consumption and savings decisions to take these expected payments into account.

This suggests that we should check whether the difference in total expenditures arises from new transfers or simply interest payments and anticipated transfers. In order to make this calculation, we need data on transfers. There are two large transfers made by the Japanese government to Japanese over the age of 64: public pension payments and medical benefits. ${ }^{17}$ Fortunately, Faruqee and Muhleisen (2001) built a dataset using Japanese SNA data that carefully breaks out transfers to those over 64 from total government outlays. If we subtract transfers to the elderly and interest payments on debt from total expenditures, we obtain the thin line in Figure 2.2. The striking feature of this plot is that total expenditures less those for interest and elderly tracks the SNA public demand expenditures data very closely. The only difference between the two lines is due to transfer payments to those less than 65 , which are small and

\footnotetext{
${ }^{17}$ It is important to bear in mind that although "shakai hoken" is translated in most government publications as "social security" the better translation is "social insurance" as these data include a large amount of benefits, such as unemployment benefits and child welfare benefits, that would not be included in a US definition of social security. This difference means that one cannot simply compare US "social security" payments with the Japanese ones.
} 
stable relative to GDP. Moreover given that gross interest payments on Japanese debt have remained between 3 and 4 percent of GDP for every year between 1981 and 2000, it is clear that the increase in government expenditures since 1996 is due overwhelmingly to transfers to the elderly.

The dramatic rise in elderly expenditures might be stimulative if it arose from an unexpected increase in benefits to the elderly. One reasonable assumption as to how people expect elderly benefits to rise is that they will rise roughly in proportion to GDP. As one can see in Figure 2.3, after an initial run up in the early 1980s real per capita transfers to the elderly (i.e. those over age 64) has tracked real GDP relatively well for the last fifteen years. ${ }^{18}$ This suggests that the recent increase in elderly expenditures is explained not by an expansion of per capita benefits for the elderly but rather by the fact that the number of elderly eligible rose sharply. A similar story seems to apply for real expenditures other than those on the elderly and interest: computed on a per-non-elderly person basis, the Figure shows these roughly tracked real GDP between 1980 and 2000 .

Alternatively, it is also reasonable to suggest that people might expect that government transfers to each elderly person will track the real per capita income of the working age population. This would be the case if government expenditure on the elderly maintained the income of elderly relative to the income of wage earners. One obtains a similar picture if one looks at real per capita benefits relative to real per capita GDP. Between 1980 and 2000 real per capita benefits for those under age 65 rose on average 0.4 percent faster than real per capita income. Similarly between 1986 and 2000, real per capita elderly benefits rose 0.3 percent faster than real per capita GDP. All of this increase was due to the decline in per capita income after 
1997. If real per capita GDP had grown after 1997 at the same rate as it had from 1990 to 1997, per capita expenditures and real per capita GDP would have moved at the same rate.

This discussion of government expenditures reveals a number of key points that we will use in our sustainability calculation. The substantial increase in the government deficit was due to three factors. First poor economic performance coupled with some tax cuts lowered tax revenues by approximately 3 percentage points of GDP; second poor economic performance coupled with a fiscal stimulus in the early nineties raised expenditures by 4 percentage points of GDP; and third an aging population required greater transfers. It is also important to bear in mind that there has been no dramatic increase in real per capita elderly benefits relative to GDP or GDP per worker. Since the mid-1980's per capita transfers to the elderly have risen roughly in proportion to GDP per worker or GDP. In other words, the growth in government expenditures is due principally to the number of people receiving benefits rising not to dramatic increases in benefits per recipient.

To return to the sustainability calculation, we make use of several stylized facts. Government outlays have demonstrated some volatility in response to business cycles but the ratio of pension and medical outlays per elderly person relative to GDP or GDP per capita has been essentially flat. The same can be said for all other outlays (except interest) on a per nonelderly person basis. We therefore use the average of these variables over 1980 to 2000 as our estimate of the baseline level of outlays per capita. This avoids the problem of having our results

\footnotetext{
${ }^{18}$ All "real" expenditure levels are deflated by the GDP deflator. 1986 marks a break point in the series because a number of cost control measures were introduced in that year to contain growth in benefits for the elderly. Data is from Faruqee and Muhleisen (2001).
} 
affected by fluctuations in expenditure levels that are driven by business cycles but does allow the outlays to fluctuate with population shares. ${ }^{19}$

One way to check the reasonableness of our assumptions is to use them estimate Japan's structural deficit - i.e. a deficit when cyclical factors are removed - and then compare our forecast with that of the OECD. It would be disturbing if our approach could not explain a large share of the deterioration in Japanese government accounts. This is potentially a difficult hurdle since our model of government expenditures is quite simple - the deficit as a share of GDP is the average ratio per capita expenditure to GDP between 1980 and 2000 times the number of people in each category plus interest expenses less the historical average tax to GDP ratio. Hence the only thing that moves our forecast of the deficit around is the number of elderly and non-elderly.

Using this methodology, we forecast Japan's structural deficit for 2005 to be 6.3 percent of GDP. By contrast, the OECD (2003) forecast for the structural deficit in 2005 is 6.6 percent of GDP. The closeness of these two numbers is striking given that the OECD obtains its estimate through sophisticated econometric techniques whereas ours is simply obtained by holding fixed historical per capita expenditure levels. Moreover, if we use our methodology to "forecast" the deficit in 1990, we find that Japan's structural deficit was only 3.1 percent of GDP in that year. Hence, our methodology can explain the very sharp deterioration in government finances that we observed in the 1990's and yields plausible estimates of the deficit. This gives us confidence that our methodology is a sensible way of thinking about the evolution of government finances.

\footnotetext{
${ }^{19}$ Studies that use simple indicators of fiscal sustainability (e.g., Alexander (2000) and Dekle (2001)) use current levels of expenditure as their baseline assumption and do not separate the cyclical and trend component of government expenses. These studies tend to find much bigger required tax increases because cyclical policy is mixed together with long-run policy.
} 


\subsection{Population}

Changes in birth rates take a long time to affect changes in pension levels and hence one needs to use a sufficiently long time horizon is necessary to make sure that the budgetary implications of a shift in fertility are fully captured..$^{20}$

Japanese forecasts of fertility tend to be far more pessimistic than forecasts based on economics or data. The Japanese National Institute of Population and Social Security Research (NIPSSR), which underlies many government and academic analyses of pension burdens. NIPSSR builds its population forecast by assuming that the existing fertility rate will not change in the future. ${ }^{21}$ To get some sense of what this implies, if the current situation continues - that is there is no immigration and the typical child is born to a 29 year-old woman, and the fertility rate is 1.3 , then using this methodology implies that that there will be fewer than 20,000 people under the age of 20 in around 500 years and that the last Japanese baby will be born in about 1000 years!

The implausibility of this notion underscores the problem of building a sustainability forecast based on NIPSSR data. Any social pension scheme that is financed out of current worker wages will be ultimately unsustainable if one predicts workers to disappear before the elderly do. Unfortunately, Japanese sustainability forecasts built using this data therefore basically assume unsustainability rather than being able to answer whether the Japanese fiscal situation is unsustainable. [See, for example, Dekle (2003) and Takayama, Kitamura and Yoshida (1999a and 199bb); a notable exception is Faruqee and Muhleisen (2001)]

\footnotetext{
${ }^{20}$ The difference between the birth rate and fertility rate is important, and our concern is primarily with the latter. The fertility rate is the number of children a woman has over her reproductive life. The replacement level - the fertility rate necessary to sustain a constant population — is about 2.1 , the 0.1 covering those who do not themselves procreate. The birth rate refers to the ratio of births to current total population, and thus is affected by the proportion of women of childbearing age in the population.

${ }^{21}$ The National Institute of Population and Social Security Research Medium Variant Forecast is the standard one used in government publications and in academic research such as Dekle (2002).
} 
An alternative approach is to make use of economic demography. Economic demographers typically assume that two forces are likely to be important in determining fertility rates. The first is the substitution effect and the second is the income effect. As wages rise, the opportunity cost of having children rises and fertility falls. In other words, higher wages cause people to substitute working more on their careers and earning more money for having children. However, if wages rise enough, the marginal utility of income starts to fall and families become more likely to decide to have children. Put simply, while having both spouses work matters a lot for the typical household, it probably does not matter so much for wealthy households. The question, of course, is how much money is enough to cause the income effect to dominate. Figure 2.4 plots international fertility rates against per capita GDP. ${ }^{22}$ As one can see in the figure (and in regression analysis), the trough in fertility occurs at a PPP GDP per capita of 25,000 dollars - precisely the level that Japan is at now. ${ }^{23}$

Theory and empirics, therefore, indicate that Japanese fertility rates will not remain low forever, but rather will rise at some point in the future. This suggests that the long-run population of Japan will be lower than the current level, but not zero, which has important implications for sustainability calculations. Managing a demographic transition from a high population to a lower one is much easier than managing a transition towards zero: the key difference is the temporary nature of the budget shortfall necessary to cover the temporarily high share of the elderly in this long-run perspective.

\footnotetext{
${ }^{22}$ PPP per capita GDP data was taken from the World Bank's World Development Indicators Database for the year 2001. Fertility data reported in the WDI is from the United Nations (2003).

${ }^{23}$ This corresponds to $\mathrm{e}^{10}$. While one should not make too much of the precise location of the trough, it is clear that decline in fertility tapers off and appears to rise.
} 


\subsection{Effects on Policy Options}

Using forecasts based on the premise that Japanese will continue to exist, policy options abound. An important option arises from the fact that although the social pension scheme is often billed as a pay-as-you-go system, in reality it is nothing of the sort. Until 1994, Japan's relatively young population meant that social security payroll taxes exceeded expenditures and the future is likely to entail deficits for many years. This is a natural outcome of a process in which the costs of the social pension scheme are smoothed across generations. The alternative would be to have even lower taxes in the 1980's and 1990's and extremely high taxes in the future. However, once one realizes that the Japanese government does smooth the costs of the demographic transition (i.e. making current generations pay for future retirements), the next question is whether this smoothing can be used to alleviate some of strain associated with the aging society.

To answer this we need to be clear about the time period of the demographic transition. We will use annual forecasts of the Japanese population constructed by Faruqee and Muhleisen (2001) who project that the population of Japanese aged 15-64 will stabilize in 2060. Despite this ultimate stabilization in population, Faruqee and Muhleisen's forecasts indicate that in 2060 there will be 29 percent fewer Japanese in this age bracket than there are now. This suggests that even if one believes that ultimately Japan's fertility rates will recover, it will still take more than half a century for the size of the Japanese labor force to stabilize.

One implication of this is that it can make a very big difference to a sustainability calculation whether one expects the demographic transition to be paid for within 40 years as is often assumed or in 100 years. The intuition is as follows. If the Japanese population is moving towards a new stable lower level, then the aging of the population is a temporary phenomenon that will ultimately disappear after the generations with the low fertility rates die. Because the 
cost of the transition is temporary, one can reduce the per capita cost of this transition by spreading it out over current and future generations. In other words, spreading out this temporary cost over all the people who work over a 100 year period may result in significantly lower taxes for the current generation of workers relative to spreading it out only over 40 years, and dramatically lower taxes than the current government plan to eliminate the primary deficit by 2012.

\subsection{Interest and Growth Rates}

An interesting feature of the mathematics underlying sustainability is that one does not need to take a strong stand on the level of interest rates and growth rates but simply their relative level. ${ }^{24}$ Obviously, forecasts of the gap between interest rates and growth 100 years hence can be little more than educated guesswork. We therefore opted to put forward a number of scenarios that should capture most people's assumptions about what the future is likely to look like. The basic intuition about this gap arises from assumption one makes regarding whether Japan still needs to raise its capital to GDP ratio. Higher interest rates ceteris paribus yield more savings and more rapid capital accumulation. Theory suggests that if the Japanese capital to output ratio is to remain stable, it should be the case that interest rates should equal the growth rate, i.e. no gap. On the other hand if one believes that Japan is still converging to an even higher capital to GDP ratio than it has now, then one should use a positive gap between interest and growth rates with more positive gaps associated with more rapid increases in capital accumulation.

The correct gap, however, is clearly a judgment call. As Blanchard et al (1990) note, 
increasing this gap affects the calculation in two opposing ways. First a higher interest rate gap tends to raise the sustainable tax rate because it raises the cost of servicing any existing level of debt. On the other hand, a higher gap lowers the cost of an aging society because future costs are discounted at a higher rate. Blanchard et al (1990) recommend using a gap between interest and growth rates of two percentage points even though in many countries the gap has been much smaller in recent decades.

Japan is a case in point. In the 1960's and the 1970's the average difference between the average yield on Japanese government bonds and nominal GDP growth was negative [Source:

IMF, International Financial Statistics Yearbook]. In the 1980's the gap was 0.4, and in the 1990's it was still only 1.4 percent. Hence, our baseline specification, which is based on a gap of 2 , is relatively high in light of Japan's experience in the last four decades.

\subsection{Future Government Expenditures}

There is far less agreement on the determinants of political economy than on growth. In general, government expenditures are forecasted using assumptions about the rates of growth of expenditures on different population groups. It is useful to write the total expenditure per capita in period $t$ as follows:

$$
\text { Total Expenditure per capita }{ }_{t}=\frac{(1+\gamma)^{t} H_{0}}{n_{\text {old }, t}} \times \frac{n_{\text {old }, t}}{n_{t}}+\frac{(1+\mu)^{\mathrm{t}} G_{0}}{n_{\text {young }, t}} \times \frac{n_{\text {young }, t}}{n_{t}}
$$

\footnotetext{
${ }^{24}$ As one can see from equation (5) the discount factor depends only on the ratio of one plus the interest rate to one plus the growth rate. For small growth rates, this ratio is almost independent of the actual growth rate, and hence we focus on the interest rate gap. In practice, we used a GDP growth rate of 2 percent per year and assumed per worker income growth equaled the growth rate less the growth rate in the labor force. Changing the growth rate from 2 percent to 0 percent change our sustainable tax rates by less than 0.1 percentage points in our base case scenarios.
} 
where "young" is defined as the population of 64 years of age and below, $n_{t}$ is the total population in time $t$ (i.e., $n_{t}=n_{\text {old }, t}+n_{\text {young, }, t}$ ), and $\gamma$ and $\mu$ are the rates of growth of the expenditure per old and young, respectively.

We consider three possible versions of future government expenditures.

Case 1, the most common in the literature, assumes that i) per person government transfers to the elderly, $H / n_{\text {old }}$, rise at the same rate as real GDP (i.e., $\gamma=g$ ); and ii) per person government expenditures unrelated to elderly benefits and interest payments, $G / n_{\text {young, }}$, grow at the rate of GDP minus the rate of growth of the young population (i.e., $\mu=g-\pi_{\text {young, where }}$ $\pi_{\text {young }}$ is the rate of population growth of the young). The first assumption implies that per recipient transfers to the elderly as a share of GDP remain constant over time. The second implies that per recipient expenditures on the young as a share of GDP grow at the rate of decline of the young population. In other words, if the share of young in total population is falling over time this implies that non-elderly related government expenditures per young person are an ever increasing share of GDP. ${ }^{25}$

This asymmetry in government expenditures assumed in Case 1 is unlikely to be true in practice because if per recipient expenditures on a demographic category are constant then aggregate expenditures should depend on the number of people within that category. Put

\footnotetext{
${ }^{25}$ Blanchard et al (2000) assume that the non-elderly expenditures grow at the same rate as GDP. This assumption implies that per-capita expenditure to people below 65-years of age is monotonically increasing over time as a share of GDP. As suggested above (see Figure 2.3), this has not been the behavior of per-capita expenditures on this age group in the last 20 years. In their study of OECD countries, Dang et al (2001) recognize that education and child/family benefits fluctuate with the number of young but, in the case of Japan, do not have enough data to correct their expenditure forecasts. Dekle (2002) assumes a constant share of GDP is spent on education per young. Blanchard et al (2000) and Dang et al (2001) assume that the percent change in the ratio of public pension expenditure to GNP is the same as the percentage change in the old-age dependency ratio. This amounts to an
} 
differently, if an aging population means an increase in government transfers to the elderly, then by the same logic, a drop in fertility rates should mean a decrease in expenditures on younger Japanese. Fewer young people should mean fewer schools, fewer police, and less unemployment insurance. This suggests that in the case of a population that is contracting at the same time it is aging, as is the case in Japan, there is an important cost offset associated with reductions in expenditures on the young. Unless one builds this into the calculation, one will significantly overestimate future expenditures. This problem raises the question of what the right future path of expenditures is likely to be. It seems unlikely that Japanese would easily accept a decline in per capita government services, but how rapidly must they rise?

Case 2 is a little less generous to the young than Case 1: all per capita transfers rise in proportion to GDP. In terms of equation (6), this implies that, $\gamma=\mu=g$. That is, non-interest expenditures for different population groups are treated symmetrically and grow at the rate of GDP.

Case 3 is a more generous expansion of public goods and transfers in that the growth of all per capita transfers rises proportionally with per worker GDP growth. This implies that $\gamma=\mu$ $=g-\pi_{w p}$, where $\pi_{w p}$ is the rate of growth of the working population.

For Japan, as the working population is falling over the entire forecasting horizon, Case 3 implies a higher growth rate of per capita expenditures than Case 2. It is important to remember, however, that both forecasts imply very substantial increases in the amount of government services and transfers provided to the typical Japanese person over the next century. In other words, assuming a 1.5 percent real per capita income growth rate (which is slower than the 
growth rate of real per capita GDP between 1989 and 2002), the real value of per capita government outlays rises by 3.25 or 4.4 times in Case 2 and (3), respectively, over the next 100 years - in either case a significant improvement over current levels.

Figures 2.6 through 2.8 show the evolution of total transfers to each population group as a share of GDP under the three different cases. These figures use the population projections from Faruqee and Muhleison (2001) described in previous sections. ${ }^{26}$ Figure 2.6 highlights the path of expenditures under the assumptions of Case 1. It shows the rising transfers of the elderly as a share of GPD until 2050, and the constant share of GDP that corresponds to the young (assumption ii)). In this scenario, total government expenses as a share of GDP peak in 2050 at a level of 38.3 percent of GDP. Figure 2.7 shows the offsetting cost of expenditures on the young under the assumption that expenditures for different population groups are treated symmetrically and grow at the rate of GDP (Case 2). As opposed to Case 1, this scenario predicts that aggregate government outlays will rise over the next 20 years and reach 35.5 percent of GDP, Total expenses will then gradually fall to levels last seen in the 1980's by the end of the twenty-first century. Finally, the last figure shows the much more generous welfare program suggested by Case 3, where per-capita expenditures are assumed to grow at the rate of GDP per worker.

\section{Sustainability}

The mathematics underlying sustainability suggests that unless monetary policy, taxes, and expenditures are precisely aligned, there will be a tendency for the debt-to-GDP ratio to rise or fall. Hence, we are less interested in the knife-edge result of whether taxes and expenditures

\footnotetext{
and is similar to having elderly outlays grow with GDP per capita.

${ }^{26}$ Transfers to the elderly per old, $\mathrm{H}_{0} / \mathrm{n}$ (old), and rest of expenditures per young, $\mathrm{G}_{0} / \mathrm{n}$ (young) are assumed to be at their average level between 1980-2000. Using the NIPSSR population projects we would face even more dramatic changes in the per-capita expenditure levels over time.
} 
are perfectly aligned, than in how much taxes need to move in order to achieve sustainability. ${ }^{27}$ If a small movement is needed then one should have little concern about sustainability. On the other hand, an implied large movement might be grounds for worry.

This, of course, raises the question of how big is big? We can think of three sensible answers. The first is anything bigger than zero. The second is raising taxes up to the levels they were before the tax cuts of the 1990s. Third is an increase that would raise Japanese taxes above the level of the typical OECD or European economy. To make these numbers concrete, consider that the average rate of government revenue to GDP in Japan between 1990 and 2000 was 32.2 percent. ${ }^{28}$ This number serves as our baseline for the long run Japanese tax rate. Government revenue as a share of GDP peaked in 1990 at 34.3 percent just prior to a series of tax cuts designed to offset the bursting of the bubble. This implies that a Ministry of Finance policy that took Japanese tax rates back to their 1990 level would increase revenues by approximately 2 percentage points of GDP.

The third criterion entails an increase that would raise taxes above a typical OECD or European economy. In order to understand the last criterion we need comparable international tax data. The OECD provides data on current government receipts relative to GDP, which is a comprehensive statement of taxes and other transfers to the government. ${ }^{29}$ Figure 2.5 presents this data for OECD countries in 1997, the last year for which comparable data were available for the US. The striking feature this graph is that Japanese taxes are the second lowest in the OECD - almost 3 percentage points of GDP below government revenues in the US! Raising Japanese

\footnotetext{
${ }^{27}$ For the time being, we are going to assume that taxes are the only means of attaining sustainability. We will return to monetary policy later.

${ }^{28}$ Revenue and expenditure data are from Faruqee and Muhleisen (2001). Government revenue in 2000 was 31 percent of GDP. They obtain their data from the system of national accounts.

${ }^{29}$ Data is from SourceOECD website. As the OECD explains, "current receipts consists mainly of taxes on production and imports, property income receivable, current taxes on income and wealth receivable, social contributions and other current transfers."
} 
taxes to the average level for the OECD would entail a tax increase in Japan of 6.3 percentage points of GDP, and raising them to EU levels would entail a whopping 13.6 percentage points of GDP increase in tax rates or a 50 percent rise in Japanese government revenue.

\subsection{Our Estimates}

With these benchmarks, we can turn to our estimates. A lot of assumptions are behind any sustainability forecast. Reasonable people can (and do) disagree about the future level of interest rates, GDP growth rates, government expenditure growth, future monetary policy, and fertility rates. While we believe that certain assumptions are more reasonable than others, we think that providing a range of estimates to cover all reasonable outcomes is a more sensible way of handling the inherent uncertainty about what the future is likely to look like. In this section we assume that changes in money supply are not used to finance government expenditures (i.e., $\lambda=$ 0 in equation (3)). We will assess the impact of monetary expansions on the sustainability calculation in the next section.

Tables 2.1 and 2.2 present the results from all of our simulations of the future. We will discuss the results starting with the most pessimistic view of the future from the sustainability standpoint and move towards more optimistic views. In all of these cases we assume a real GDP growth rate of 2 percent. ${ }^{30}$ Sustainability is calculated either to 2100 (that is, the debt-to-GDP ratio in 2100 must equal that of today) or to 2040. (For convenience, calculations to 2100 are referred to as being over a 100-year period, and to 2040 over a 40-year period.) Columns 1 and 2 presents results using NIPSSR population estimates, and Columns 3-5 use Faruqee and Muhleisen (2001). The difference between the variables in each column is the difference 
between sustainable tax rate under different the interest rate and the growth rate assumptions.

Changes in the money supply are not used to finance government expenditures (that is, $\lambda=0$ in equation (3)) except in the last row, as discussed later.

In column 1 of the first panel, we assume that Japan is on the road to developing an extremely generous welfare state in which all public expenditures will rise proportionally to GDP per worker (i.e., Case 3 in the previous section). In the scenario where the interest rate gap is 2 percentage points, we find that the sustainable tax rate is 43.9 percent. The assumptions underlying this scenario are so pessimistic that we obtain some perverse results. Because we assume that the per capita costs of elderly will rise with per capita income, future costs matter much more than past debt levels. As a result, the sustainable tax rate is lower when growth is low relative to interest rates because high interest rates enable the government to run surpluses today and use the interest on the surpluses to pay for the future retirees. This also explains why moving to a 40 year horizon causes the sustainable tax rate to fall. The combination of an ever shrinking labor force and ever higher retirement benefits means that it becomes increasingly hard to pay for the retirees. As a result one needs lower taxes to pay for retirees over a 40-year period than over a 100 -year period.

One argument against believing this scenario is that perhaps we have stacked the data too much against sustainability and therefore employed odd assumptions that yield odd results. However, pessimists might truly worry about a collapsing Japanese population in the face of a government unable to rein in expenditures. Indeed, given that the tax rates in this bleak scenario exceed the 32.2 percent average tax rate for the 1990's, the scenario implies that Japan must raise

\footnotetext{
${ }^{30}$ In robustness checks we found that assuming the same interest rate gap and a real GDP growth rate of 0 percent did not affect the first three digits of the numbers so we do not report those results here.
} 
its taxes substantially, i.e. approximately 10 percentage points of GDP. ${ }^{31}$ However it is important to bear in mind that the implied tax rates are still lower than those currently being paid in the typical EU country or even in Canada.

In other words, if the Japanese want per capita government expenditures to rise at the same rate as per worker income, they are going to have to pay for it. Put differently, in order to justify default as an option in this most generous social welfare case and most pessimistic population growth case, one has to assume that default is a better option for the Japanese government than the tax rates of the typical EU country. It seems hard to imagine the Japanese government making this decision, and this probably explains why the bond market is not anticipating a default.

Other scenarios are better from a taxpayer standpoint. Suppose that instead of using the NIPSSR population estimates we switch to the IMF [i.e. Faruqee and Muhleisen (2001)] estimates which allow the population to stabilize at a new lower level. In these forecasts, the number of Japanese under age 15 relative to those 15 to 64 does not stabilize until 2045, but this makes a big difference in the sustainability calculations. Using this more optimistic forecast of the Japanese population but the same assumptions underlying Case 3, reduces the required tax rate by 2.8 percentage points of GDP. ${ }^{32}$ While this still implies an increase in taxes of 9 percentage points of GDP, the implied sustainable tax level is now only the level of the average tax rate in the typical OECD country. ${ }^{33}$ In other words, if one accepts that the Japanese population is likely to stabilize, then the sustainable tax rate for Japan looks like the typical tax

\footnotetext{
${ }^{31}$ Adjustments of this magnitude periodically do occur. Between 1970 and 1997, 16 out of 23 OECD countries for which we have data raised or lowered their tax rates by 9 percentage points or more. Of these cases, 9 countries raised government current revenues by 9 percentage points of GDP in ten years or less.

${ }^{32}$ The path of expenditures in this case corresponds to Figure 2.6.

${ }^{33}$ Interestingly, in these scenarios it still is the case that the spreading the benefits over 100 years is worse than over 40 years because the demographic transition takes a long time to complete and we are assuming very generous benefits for people in future generations.
} 
burden in an OECD country. While this clearly implies some painful adjustment, it hardly seems grounds for deep worry about a fiscal crisis.

Up until this point, we have been assuming that the Japanese will want to pay for very generous growth in real benefits (Case 3). It is also possible that Japanese may want to slow down the growth of benefits somewhat during this demographic transition. In particular, it makes sense to consider the case in which per capita benefits grow at the same rate as GDP, rather than GDP per capita (i.e., Case 2). Note that this still implies that there is enormous growth in real benefits with the only restriction being that there is a little more fiscal discipline in the expansion of these benefits.

In column 3 of the second panel, we consider Case 2 for the 100-year horizon using the IMF [Faruqee and Muhleisen (2001)] population projections. The magnitude of the sustainable tax rate is dramatically lower. In order to afford this growth rate of expenditures and assuming an interest rate gap of 2 percentage points, Japanese tax rates only need to rise to 34.6 percent of GDP: about the same level as in 1990! In other words, if benefits rise a little less rapidly than per capita income, then Japanese debt is sustainable with a tax burden that is on the order of the US level or the level in Japan before the bubble burst. An important reason for the relatively optimistic forecast that we obtain is that we treat young and old symmetrically - i.e. for a given per capita expenditure level, the aggregate expenditure level is determined by the number of people in each category. This is contrast to other forecasting frameworks (e.g. Dekle (2002), Dang et al (2000), Faruqee and Muhleison (2001)) which effectively assume that the remaining non-interest expenses do not decline as the number of people under the age of 65 declines. Implicitly this approach can imply very large per capita gains for the young as expenditures stay constant relative to GDP but the number of young declines. This difference can be seen in the 
path of expenses to the young in Case 2 and 3 (see Figures 2.7 and 2.8). To demonstrate the impact of this assumption, we assumed that elderly benefits grew with GDP but that the remaining non-interest related government expenditures always stayed proportional to GDP regardless of the number of young. This is reported in the last column of Table 2.2. As one can see, although the assumption that benefits to the young depend on the number of young does not alter the conclusion that Japanese tax rates need not rise above typical levels in the OECD, it does have a fairly substantial impact on the calculations if one assumes that per capita expenditures for the elderly (but not young) will increase as much as GDP. In this case, the cost savings arising from having fewer young people in the future imply that Japanese government can spend on average 3 percentage points of GDP less than one would need if expenditures on the young did not depend on the number of young.

The fact that allowing per capita public benefit levels to grow at the rate of real GDP means that only a small increase in taxes is necessary to restore Japan to fiscal soundness is a point that seems to have been missed in policy circles. Essentially the choice for Japan is lower growth rates in per capita benefits and tax rates comparable to the US or more generous growth rates in benefits and tax rates comparable to those in Europe. Which option is more attractive is something that Japanese voters will need to decide, but neither future seems bleak.

\subsection{Limiting the Debt-to-GDP Ratio}

The type of sustainability calculations used in this paper does not restrict the levels of debt-to-GDP ratios over the forecasting horizon. This implies that under certain scenarios debtto-GDP ratios may rise levels higher than financial markets are willing to accept at particular points in time. An example of this behavior is shown in Figure 2.9. The solid line represents the 
path of debt-to-GDP for the column 3 in Table 2.2, where the sustainable tax rate is 34.6 (with interest rate gap of 2). It shows that the debt-to-GDP ratio surpasses 160 percent around 2070. While these levels of debt are unprecedented even for advanced economies, we show that a small increase in the tax rate would render a path of debt that never rises above 120 percent of GDP in the next 100 years. (The 120 percent level has been observed in developed financial markets in recent years) This path is shown by the dotted line, and it represents a tax rate of just $35 \%$, an increase of only 0.4 percentage points. As we can see from the figure, a small increase in the tax rate suffices to maintain debt-to-GDP ratios at levels that have been observed in developed financial markets in the last few decades and that are consistent with the interest gaps used in Tables 2.1 and $2.2 .^{34}$

\subsection{Effect of Phasing in the Tax Increase}

Another assumption underlying this type of sustainability exercises is that taxes are increased immediately to their long-run sustainable level (in our exercise this would happen in 2005). While we see large changes in tax rates in short periods of time around the world, a more feasible tax path would probably have taxes increasing only gradually to their sustainable level over a prolonged period of time. For this reason we redid the estimates in Tables 2.1 and 2.2 with the additional restriction that taxes would only slowly converge to their long-run level. The changes in sustainable tax rates with these additional restrictions are very small. For instance, when taxes are assumed to increase linearly from the average tax rate of 32.2 percent to the sustainable tax rate in the next 10 years, the sustainable tax rate changes from 34.6 percent (IMF

\footnotetext{
${ }^{34}$ Since tax rates are assumed to be constant over the entire horizon, a higher tax rate than the sustainable tax rate implies that debt-to-GDP ratios are smaller in the end of the sustainability horizon than at the beginning. In the case depicted in Figure 9, Japan moves from a net debtor position to a net creditor position around the year 2090.
} 
population projections, interest rate gap of 2, Case 2) to 35.0 percent. In the same case using the NIPSSR population projections, the sustainable tax rates increased from 34.9 to 35.5 percent.

Obviously, there are myriad ways in which the taxes might be phased in to there sustainable levels, and it is not possible to go through all of the cases here. How certain can we be then that waiting a few years will not dramatically alter the calculations? The answer is that a rough rule of thumb about the cost of waiting to implement the sustainable tax rate is that every fifty percentage point of GDP increase in the debt level will raise the sustainable tax rate by slightly more than 1 percentage point using a 100 year horizon.

The intuition for this result stems from the interest burden of debt. If Japanese policymakers discovered that their debt to GDP ratio was 50 percentage points of GDP higher, then with an interest rate to GDP growth gap of 2 percent, this would imply that tax revenues would have to be forever higher by an additional 1 percentage point of GDP just to stabilize the debt. Paying off the additional debt over a 100 year horizon would require an additional 0.16 percent of GDP payment. Hence, even if we thought that delays in paying off the debt would result in a substantially higher debt to GDP ratio in the short term, this would not change the long-run sustainable tax rate by that much.

\subsection{Monetary Policy}

Thus far, we have been assuming that the only means available for the government to finance expenditures is through taxes (i.e., $\lambda=0$ in equation (3)). However, governments can also benefit through unanticipated inflation that lowers the real value of net debt. As shown in equation (3), a positive rate of money growth, $\lambda$, implies that for given paths of government 
expenses and taxes the accumulation of debt over time is smaller. Indeed, many analysts have been concerned that Japan's debt levels might induce the Bank of Japan to monetize the debt.

It is relatively easy within our framework to consider the impact of monetizing approximately 50 percent of the Japanese net debt (i.e. $\left.\lambda_{t} m_{t}=0.3\right) .{ }^{35}$ We implement this by considering an open market operation in which the Bank of Japan monetizes half of the outstanding government debt (i.e. increases base money by 30 percent of GDP). In the case when the gap between nominal interest rates and nominal GDP growth is 2 percentage points, this lowers the sustainable tax rate by only 0.6 percentage points. This is very small in comparison to the difference in the tax rates that arise as a result of the higher or lower growth rates in per capita benefits discussed above.

Again, the main reason for the small impact is that most of the pressure on the government budget constraint is not current liabilities, which can be affected by inflation, but future liabilities, which cannot. As a result, monetization of a significant portion of the outstanding Japanese government debt will not change the sustainable tax rate by much.

The insensitivity of these calculations to major swings in monetary policy also suggests that even if the Bank of Japan needs to ultimately reduce the money supply to mop up liquidity, this will not have a large impact on Japanese fiscal sustainability. Between March 2001 and March 2004, the Japanese money base grew by 8 percent of GDP. As the previous example indicates, even if the BOJ intervened in the market by selling off all of the bonds that it accumulated and thereby increasing our net debt number by this amount, the impact on the sustainable tax rate would only be a few tenths of a percent of GDP.

\footnotetext{
${ }^{35}$ Since our analysis is concerned with long-run sustainability we assume that changes in money supply are equal to inflation rates.
} 
Thinking about the small impacts of monetary policy also answers concerns about whether it was appropriate to consolidate bonds held by the BOJ into the government accounts. If one believes that some day the BOJ will have to sell off its entire stock of JGB's (worth 80 trillion yen in 2002) and entailing a 93 percent contraction in base money, this still would only imply that $\lambda_{t} m_{t}=-0.18$ and hence a very small implication for the sustainable tax rate.

This underscores an important reason why long-run bond rates are so low. Whatever your forecast is for the future expenditure path of the Japanese government, knowing what inflation is in the next five years will have almost no impact on sustainability. In the long run, if Japan chooses a high benefit path, the only way that it will be able to pay for these expenses is through higher taxes. Put simply, a key message from our long-run fiscal sustainability exercises is that the fiscal problem that Japan faces is future liabilities not current liabilities, and as such, inflation is not the answer to Japan's fiscal issues.

5 Conclusions and Policy Implications

This paper has argued that fiscal policy debates in Japan have been fraught with confusion over current and future liabilities. Data on current net liabilities of the Japanese government suggest that these liabilities are not so large as to be dangerous. The fact that past liabilities have not amounted to a high net debt level implies that inflation is not an answer to Japan's fiscal issues. This probably explains why Japanese interest rates have remained low in the face of sometimes shrill discussions of Japanese gross debt levels.

The relatively minor impact of large changes in Japan's net debt level on the sustainable tax rate also suggests that concerns about long run demographic transitions probably should not have much influence on short run fiscal policy. Moving the net debt level up or down by as much 
as 50 percent has only relatively minor effects on long-run sustainable tax rates. In other words, while fiscal stimulus packages in all countries imply some increase in future taxes, there is little evidence that these would push Japan over some critical sustainable tax level. However, the analysis in this paper abstracts from unsustainability that arises because of political reasons for default or self-fulfilling prophecies, which may depend on the short-run behavior of fiscal policy.

The final policy implication is that Japan's demographic transition can be manageable. The Japanese government's target of trying to restore a primary balance of zero by 2012 is a particularly painful way of handling the transition for the current generation of workers. We have considered other approaches that smooth the transition over more generations and thus would entail lower taxes in the short run (and higher ones later).

Although we don't know how generous today's young Japanese are going to be towards their parents and what their demands for public expenditures will be, we can be fairly certain of what will happen in the long run. If Japanese want to have generous expansions in government expenditures for themselves and the elderly, then Japanese government outlays and receipts will look a lot like those in Europe today. If they want to keep the real growth rate of per capita expenditures positive but only equal to GDP growth, then Japanese government outlays and receipts will look like those in the US. The bottom line is that we could construct no scenario in which Japanese tax rates needed to rise above those found in many high income countries.

The message, then, is clear. If Japanese voters want more benefits for the young and old, then they will have to pay for them, but Japan's future in this regard does not look any different than that of a typical OECD country. 


\section{References}

Abel, A., Mankiw, N., Summers, L., Zeckhauser, R. (1989) Assesing Dynamic Efficiency. Review of Economic Studies 56 (1): 1-20.

Asher, D. and Robert H. Dugger (2001), "Could Japan's financial Mount Fuji blow its top?," MIT Japan Program Meeting Proceedings No. 00-01, Cambridge (MA): MIT Press

Auerbach and Kotlikoff (1995) Macroeconomics: An integrated approach, pp. xxii, 618, Cincinnati: International Thomson, South-Western College.

Bank of Japan (2004) http://www.boj.or.jp/en/stat/stat_f.htm

Blanchard, Olivier J. (1990) "Suggestions for a New Set of Financial Indicators," OECD Department of Economics and Statistics Working Paper No. 79.

Blanchard, Olivier J., Jean-Claude Chouraqui, Robert P. Hagemann and Nicola Sartor (1990) "The Sustainability of Fiscal Policy: New Answers to an Old Question," OECD Economic Studies No. 15.

Doi, Takero and Takeo Hoshi (2002) "Paying for the FILP,” NBER Working Paper \#9385

Dang, T., P. Antolin and H.Oxley, "Fiscal Implications of Ageing: Projections on Age-related spending," OECD Economics Working Paper 305

Dekle, Robert (2002) "The Deteriorating Fiscal Situation and an Aging Population,” NBER Working Papers: 9367 (December).

Economic and Social Research Institute (http://www.esri.cao.go.jp/en/sna/qe0332/gdemenuea.html)

Faruqee, Hamid and Martin Mühleisen (2001) "Population Aging in Japan: Demographic Shock and Fiscal Sustainability," IMF Working Paper 01/40.

Frisch (1995) Government Debt and Sustainable Fiscal Policy; Economic Notes, 1995, v. 24, iss. 3, pp. 561-80

Faruqee, H. and M.Muhleisen (2001) "Population Aging in Japan: Demographic Shock and Fiscal Sustainability” IMF working paper 01/40.

Fukao, Mitsuhiro (2003) "Financial Strains and the Zero Lower Bound: the Japanese Experience Keio University, mimeo.

Hsieh, C., Hori, M and S. Shimizutani (2001), "Helicopter Drops of Money: Assessing an Unusual Experiment in Japanese Fiscal Policy," University of California mimeo. 
Japan Center for Economic Research (2000), "Long Run Forecasts of the japanese Economy," Tokyo.

Kotlikoff, L. and B.Raffelhuschen, (1999) "Generational Accounting Around the Globe," American Economic Review Vol.2, Papers and Proceedings (May), pp161-166.

Kuttner, K. and A. Posen (2001) "The Great Recession: Lessons for Macroeconomic Policy from Japan," Brookings Papers on Economic Activity, 2.

Kuttner, K. and A. Posen (2002) "Fiscal Policy Effectiveness in Japan," Journal of the Japanese and International Economies, vol. 16, 536-558.

Lebow, David (2004) “The Monetization of Japan's Government Debt,” Bank of Internaitonal Settlements, mimeo.

Madsen, Robert (2002) “Japan: Game Over,” MIT Japan Program, Working Paper Series 02.05.

Mylonas, P., S. Shich, T.Thorgiersson, and G. Wehinger (2000), "New Issues in Public Debt Management," OECD, Economics Department Working paper 241.

Muhleisen, M., (2000) "Sustainable Fiscal Policies for an Aging Population," in: JapanSelected Issues, IMF Staff Country Report 00/144.

National Institute of Population and Social Security Research Medium Variant Forecast (http://www.ipss.go.jp/English/ppfj02/t_ 1 e.html)

Organization of Economic Cooperation and Development (2003) OECD Economic Surveys: Japan Paris: OECD.

Organization of Economic Cooperation and Development (2004) SourceOECD Website, (http://iris.sourceoecd.org/vl=1017357/cl=27/nw=1/rpsv/cgi-bin/jsearch oecd stats)

Posen, Adam S. (1998) Restoring Japan's Economic Growth, Washington DC: Institute for International Economics.

Romer, D. (2000) Advanced Macroeconomics $2^{\text {nd }}$ Edition, Columbus: McGraw Hill.

Tufte, Edward R. (2001) The Visual Display of Quantitative Information. Cheshire: Graphics Press.

Takayama, N. and Y.Kitamura (1999a) "Lessons from Generational Accounting in Japan," American Economic Review, Paper and Proceedings (May), 89:2 pp171-180.

Takayama, Noriyuki, Yukinobu Kitamura, and Hiroshi Yoshida (1999b) "Generational Accounting in Japan," in Auerbach, Alan J., Laurence J. Kotlikoff, and Willi Leibfritz 
eds., Generational Accounting Around the World, Chicago: The University of Chicago Press.

United Nations (2003) World Population Prospects 1950-2050: The 2002 Revision. Database. Department of Economic and Social Affairs, Population Division. New York. 
Figure 2.1

Evolution of Japanese Government Revenues and Outlays

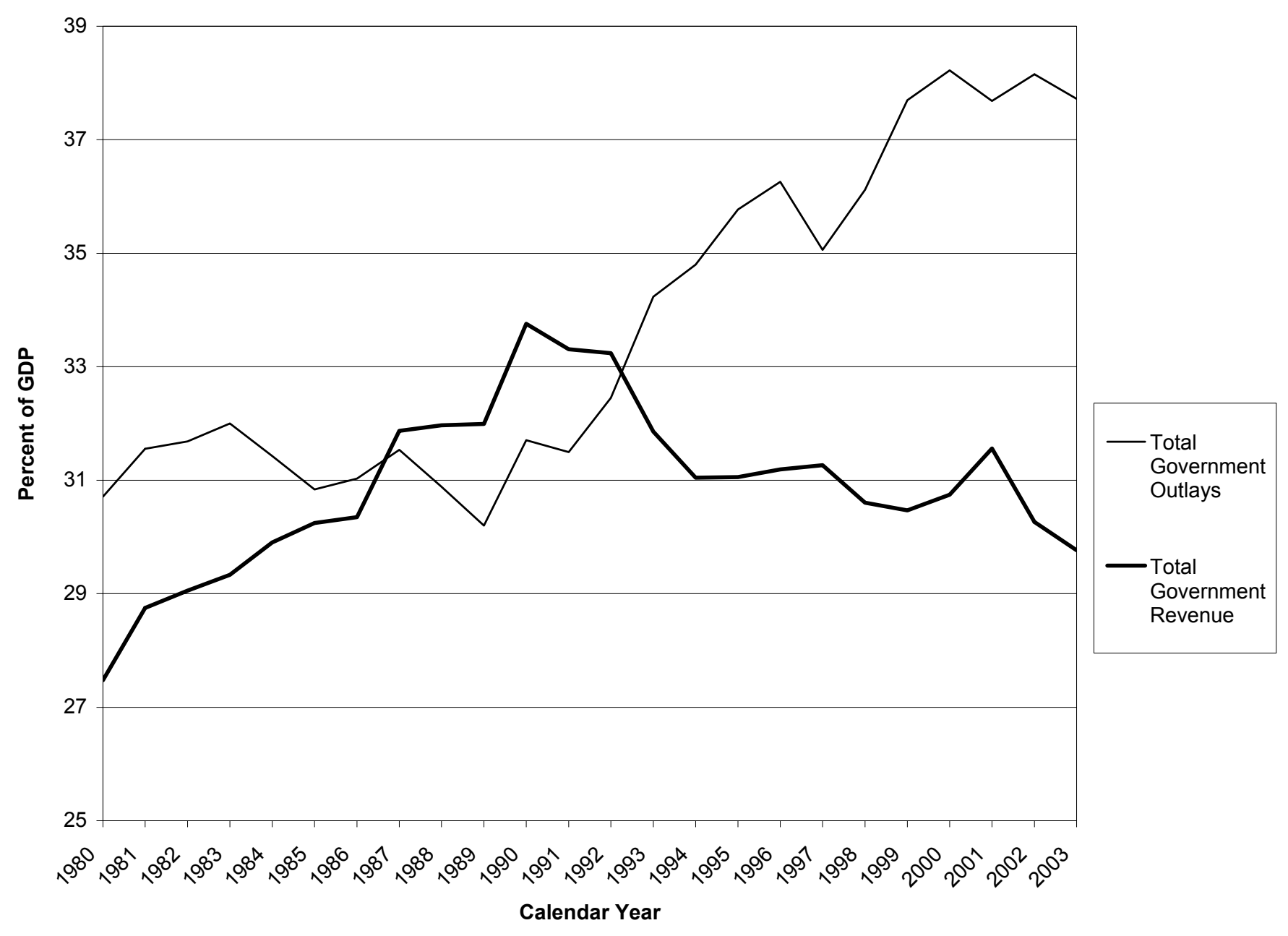

Source: OECD Economic Outlook \#75 (2004). Total Government Outlays corresponds to Total Government Disbursements Government as a percent of GDP in the source; and Total Government Revenue is Total Government Receipts. 
Figure 2.2

\section{Public Demand vs. Government Outlays}

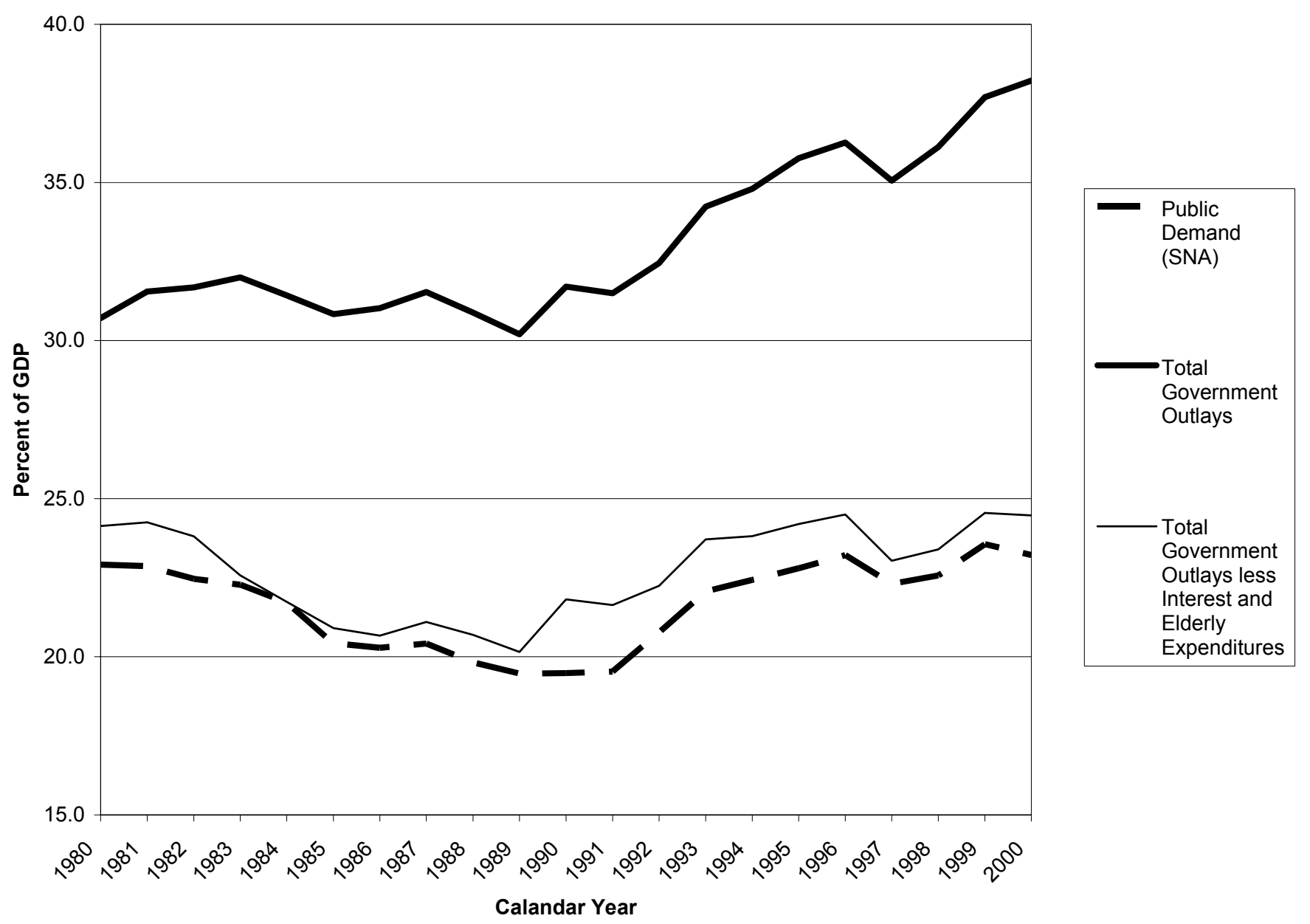

Source: Public Demand data is taken from the Economic Planning Agency SNA data. Total government outlays (Total Government Disbursements in the source) and interest expenditures (which are net) are from the OECD's Economic Outlook \#75 (2004). Elderly Expenditures are taken from Faruqee and Muhleisen (2001). 
Figure 2.3

Evolution of Per Capita Government Expenditures on Elderly and Non-Elderly in Japan (1980=1)

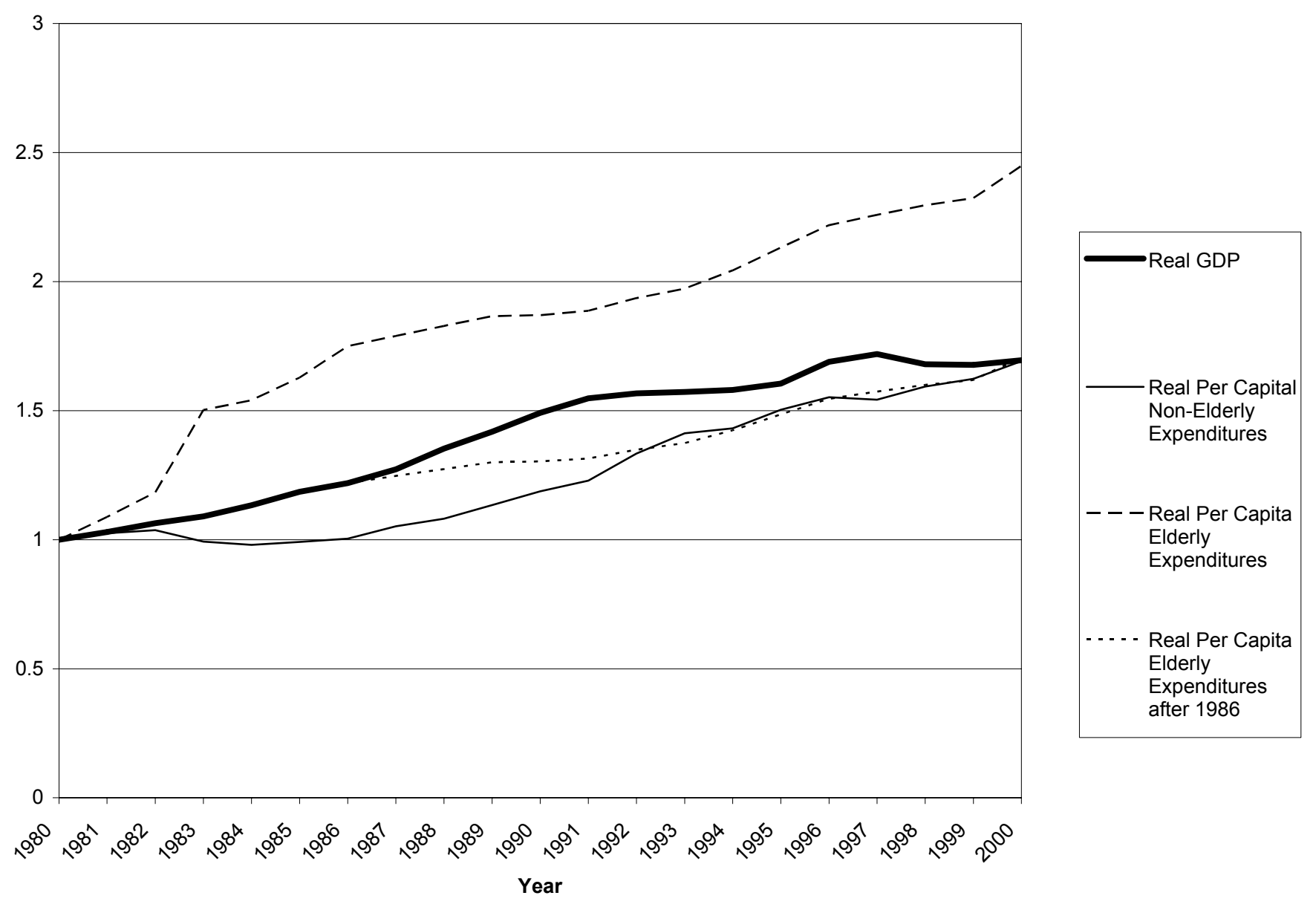

Note: Expenditures on the elderly are public pension and medical benefits for those over age 64. Expenditures per non-elderly person equal total government expenditures less those on the elderly and interest, divided by the non-elderly population. Data from Faruqee and Muhleisen (2001) 
Figure 2.4

International Fertility Rates vs. PPP GDP Per Capita

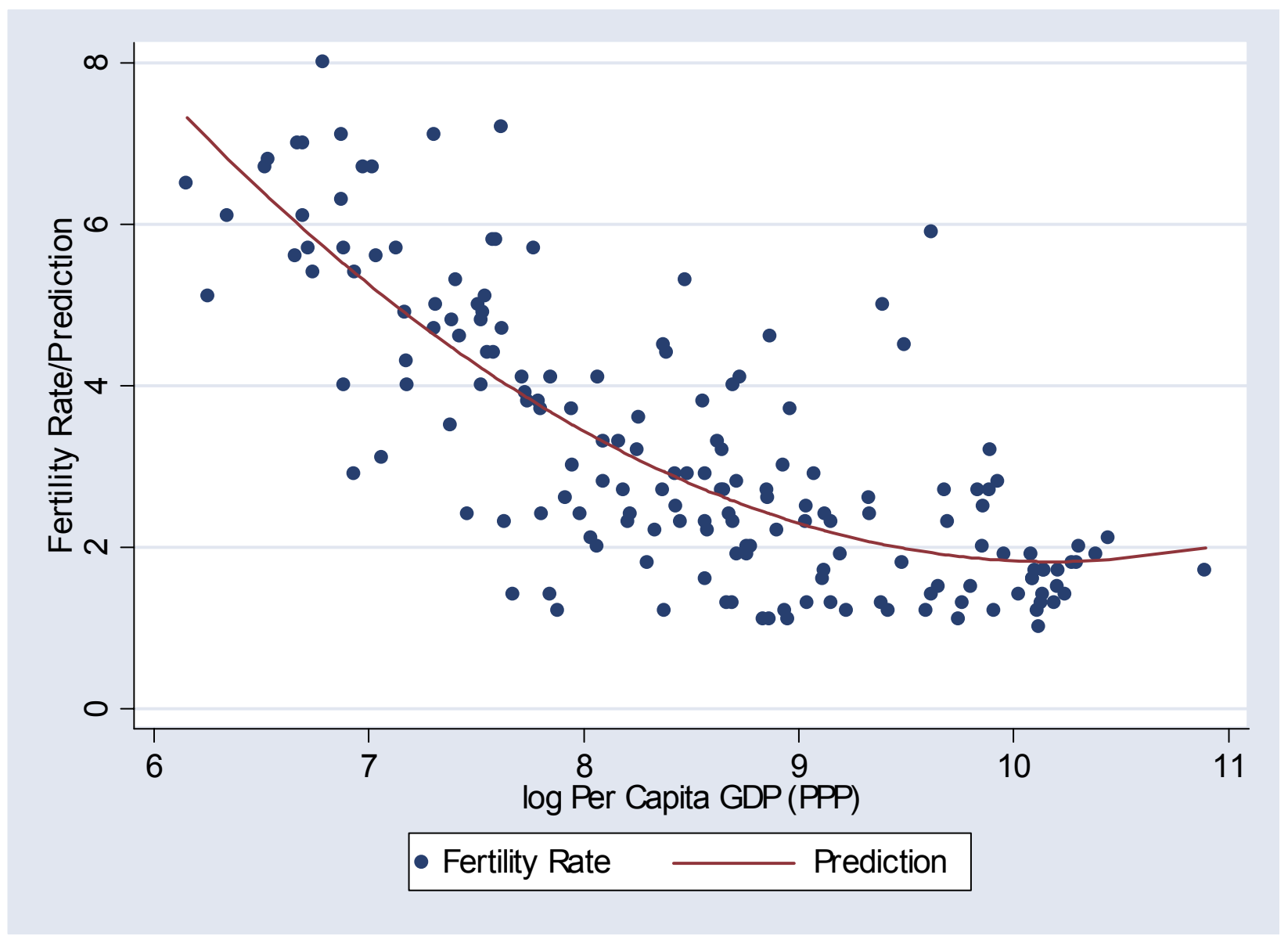

Note: These are natural logarithms 
Figure 2.5

Current Government Receipts as a Percent of GDP in 1997

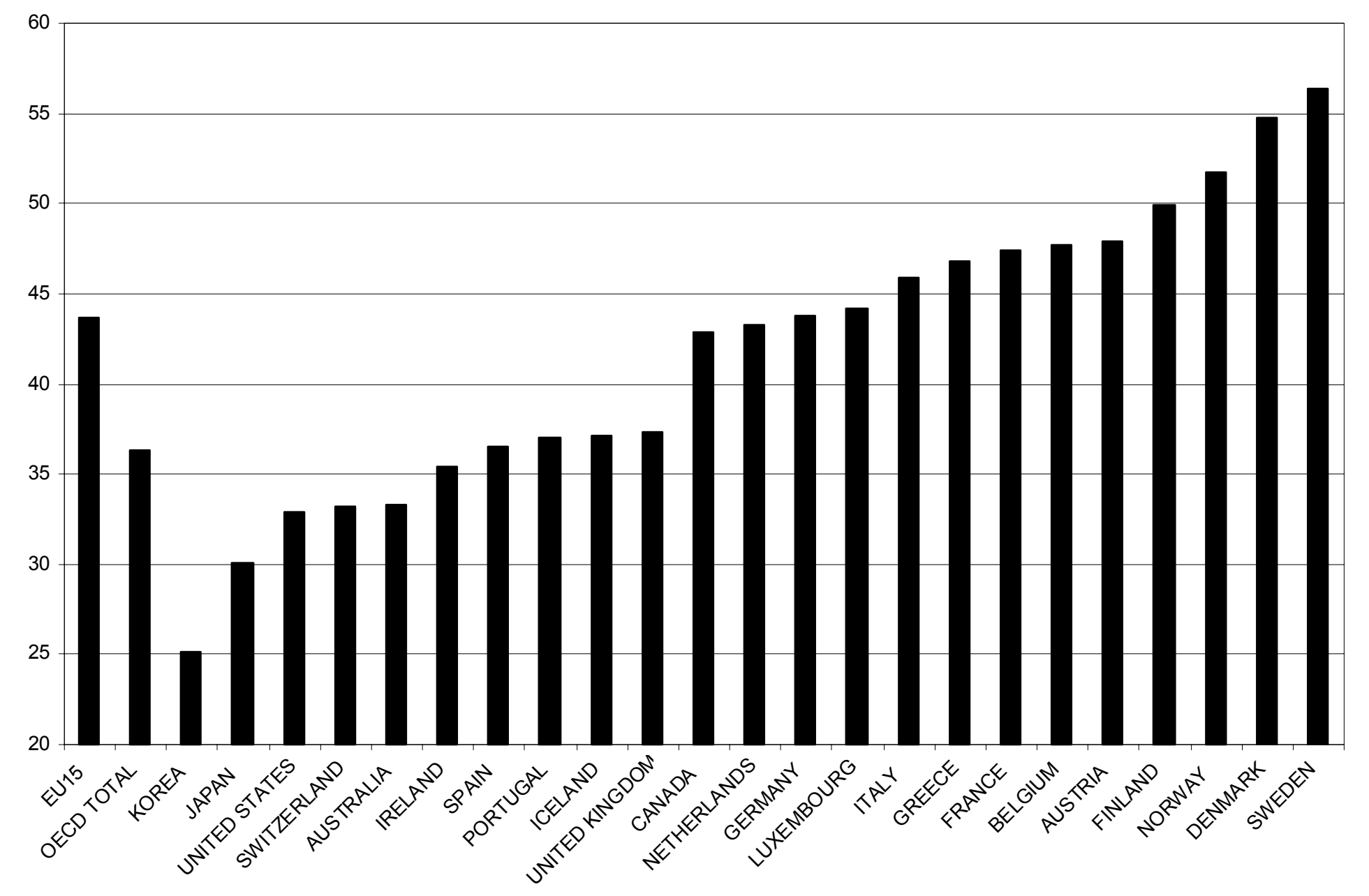

Note Data are from the OECD 
Japan 2005-2100: Projections of Government Expenses as a Percent of GDP

by Population Group under Different Scenarios

Figure 2.6

Case 1 (Assymetric: $\gamma=\mathbf{g} ; \mu=\mathbf{g}-\pi($ young))

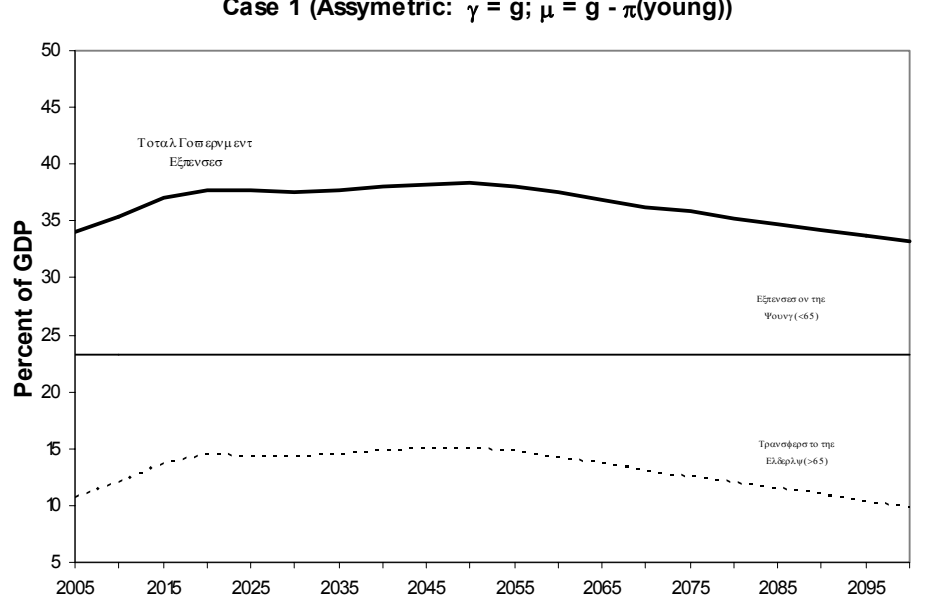

Figure 2.7

Case 2 Symmetric $(\gamma=\mu=\mathrm{g})$

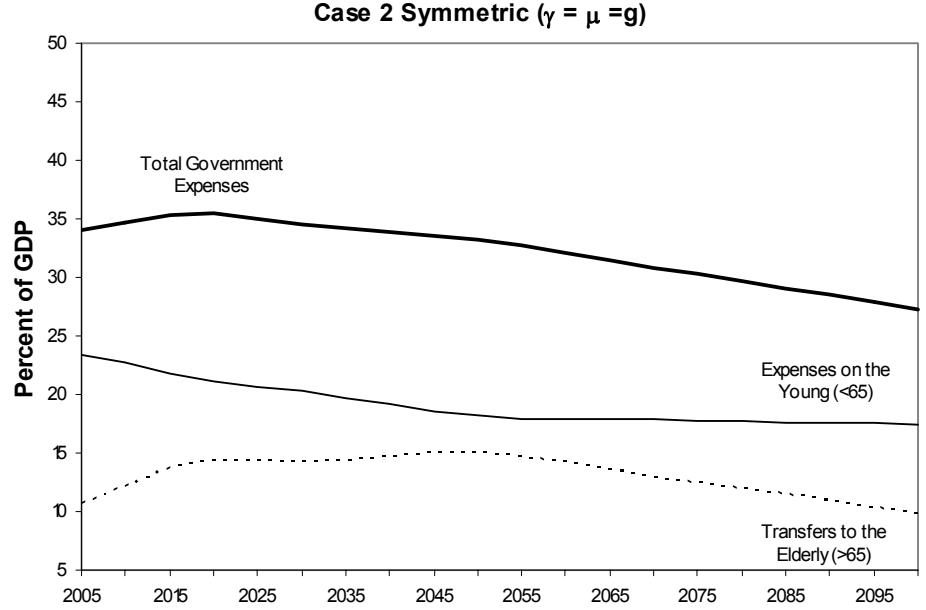

Figure 2.8

Case 3 (Symmetric $\gamma=\mu=\mathbf{g}-\pi($ working pop) $)$

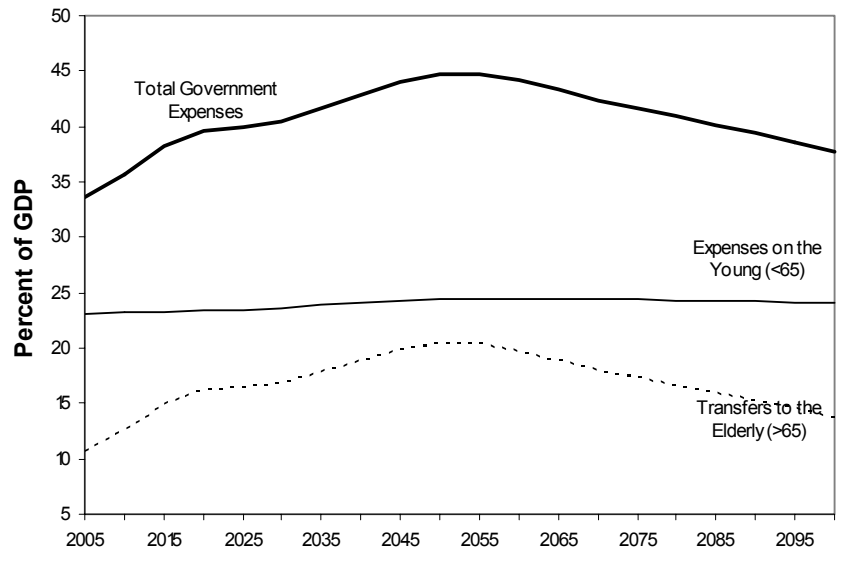




\section{Figure 2.9: Japan's Net Debt/GDP Dynamics, 2005-2100}

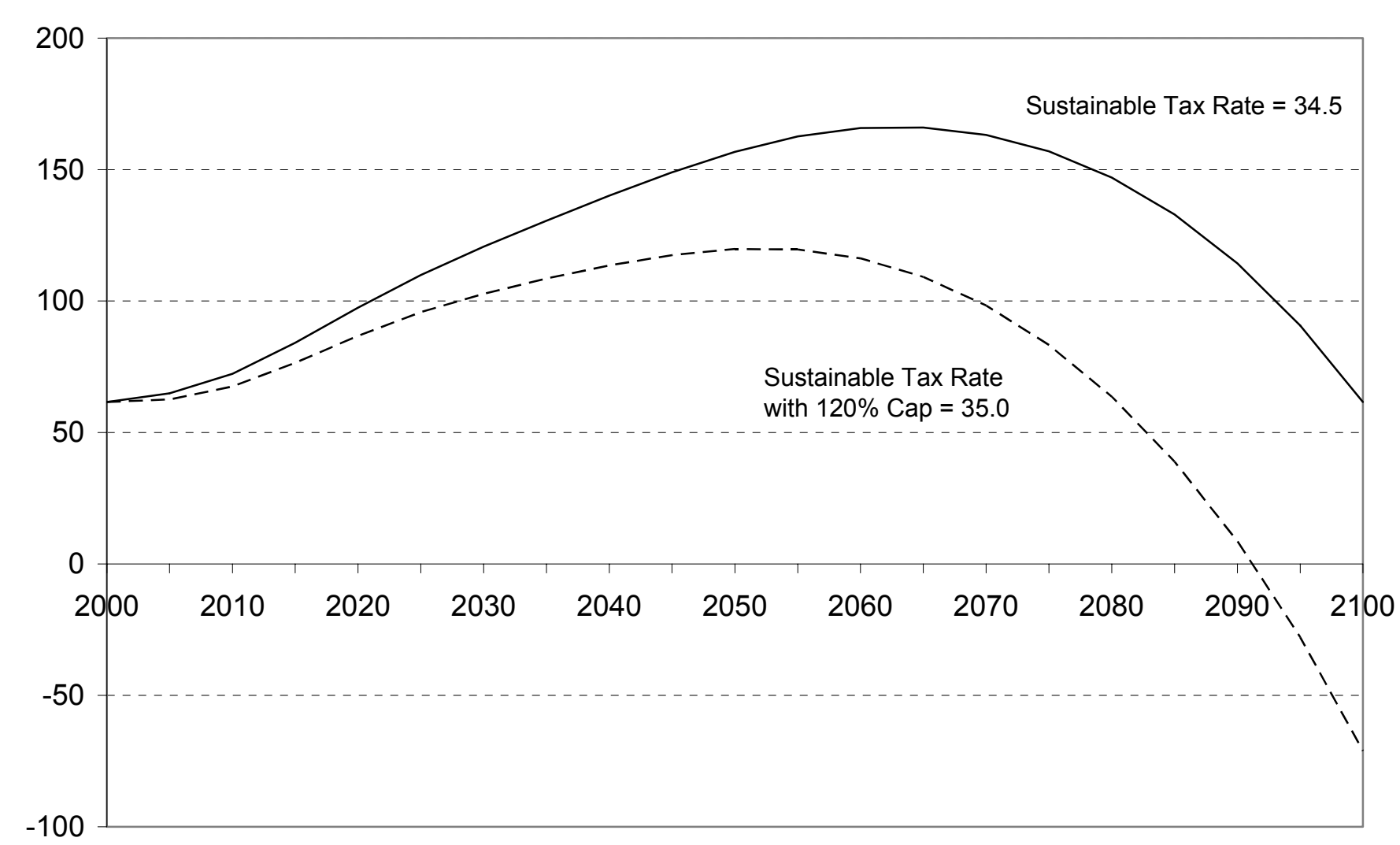

The solid line represents the path of the debt-to-GDP ratio for Table 2.2 column 3 with an interest rate gap of 2 , so the sustainable tax rate is $34.6 \%$. The dotted line is a tax rate of $35 \%$, and it stays below a $120 \%$ net debt-to-GDP level. Because tax rates are assumed to be constant over the entire horizon, a higher tax rate than the sustainable tax rate implies that debt to GDP ratios are smaller at the end of the sustainability period than at the beginning. In the case depicted in Figure 2.9, the Japanese government moves from a net debtor position to a net creditor position around 2090. 
Table 2.1

Sustainable Tax Rates with Elderly Benefits Growing Proportional to GDP per Worker, Cases 1 and 3

Sustainable Tax Rates, Cases 1 and 3

Case 3

Population Forecast

Sustainability Horizon

\section{Rate Gap ${ }^{1}$}

0

1

2

3

4

Monetary Policy ${ }^{2}$
NIPSSR

2100

44.9

44.4

43.9

43.3

42.9

43.2
40.2

40.4

40.6

40.8

41.0

39.6
IMF

2100

2040

40.7

41.0

41.1

41.1

41.2

40.5
Case 1

IMF

2100

39.7

40.1

40.4

40.5

40.6

39.7

Entries are percentages of GDP. As explained in the text, Case 3 is growth in per capita expenditures equal to per worker GDP growth, with no monetary-policy effects. Case 1 is growth in per capita elderly expenditures equal to that of per worker GDP and the share of other government expenditures to GDP remaining constant. NIPSSR means that organization's population forecasts are used; IMF means the Faruqee and Muhleisen (2001) forecasts are used.

${ }^{1}$ The rate gap is the interest rate minus the nominal GDP growth rate.

${ }^{2}$ This row shows the results of monetizing $50 \%$ of government debt. Specifically, monetary policy is used to increase M/GDP by $30 \%$ during the first 5 years.

The interest rate minus the growth rate is 2 . 


\section{Table 2.2}

\section{Sustainable Tax Rates with Elderly Benefits Growing Proportional to GDP, Cases 1 and 2}

Sustainable Tax Rates, Cases 1 and 2

Case 2

Case 1

Population Forecast

Sustainability Horizon

2100

NIPSSR

Rate Gap ${ }^{1}$

0
1
2
3
4

32.3

33.7

34.9

36.0

36.9

Monetary Policy ${ }^{2}$

34.3
35.3

35.9

36.5

37.0

37.6

35.4
2100

32.2

33.4

34.6

35.6

36.4

33.9
IMF

2040

IMF

2100

36.4

34.6

35.2

35.8

36.4

37.0

37.1

37.8

38.3

38.8

34.8
37.1

Entries are percentages of GDP. As explained in the text, case 2 is growth in per capita expenditures proportional to GDP, with no monetary-policy effects. Case 1 is growth in per capita elderly expenditures equal to that of GDP and the share of other government expenditures to GDP remaining constant. NIPSSR means that organization's population forecasts are used; IMF means the Faruqee and Muhleisen (2001) forecasts are used.

${ }^{1}$ The rate gap is the interest rate minus the nominal GDP growth rate.

${ }^{2}$ This row shows the results of monetizing $50 \%$ of government debt. Specifically, monetary policy is used to increase M/GDP by $30 \%$ during the first 5 years. The interest rate minus the growth rate is 2 . 